\title{
OSTATNIE LATA FUNKCJONOWANIA KOŚCIOLA I PARAFII PW. ŚW. JAKUBA STARSZEGO NA KRAKOWSKIM KAZIMIERZU (1758-1787)
}

\begin{abstract}
Streszczenie
W artykule przedstawiono ostatnie lata istnienia kościoła i parafii pw. św. Jakuba Starszego na krakowskim Kazimierzu. Nieistniejący obecnie kościół św. Jakuba był jedną z trzech najstarszych świątyń na Kazimierzu, obok kościołów św. Michała Archanioła na Skałce i św. Wawrzyńca we wsi Bawół. Znajdował się w centrum osady nieznanego obecnie z imienia protoplasty rodu Strzemieni. Pierwsza wzmianka o parafii pw. św. Jakuba pochodzi z 1313 r. Od początku swojego istnienia była obsługiwana przez dwóch plebanów. W 1462 r. wystawiono dokument reorganizujący strukturę kleru posługującego w świątyni św. Jakuba na Kazimierzu, znoszący drugą plebanię, a w jej miejsce ustanawiający kolegium mansjonarzy. Pozostałe probostwo, zgodnie z powszechną praktyką widoczną w XV wieku, podniesiono do godności prepozytury. Cezura czasowa artykułu została wyznaczona przez dwie daty w XVIII wieku. W 1758 r. przedstawiciele rodu Strzemieni zrzekli się prawa patronatu wobec parafii pw. św. Jakuba na rzecz biskupów krakowskich. W tym samym roku biskup krakowski Andrzej Stanisław Kostka Załuski inkorporował probostwo do prefektury krakowskiego Seminarium Akademickiego. W 1783 r., w ramach tzw. „spustoszeń” kościelnych, przeprowadzonych na polecenie prymasa Michała Jerzego Poniatowskiego, kazimierska parafia pw. św. Jakuba Apostoła została ostatecznie zniesiona. Tereny pokościelne: mury świątyni, ogród, domy proboszcza, mansjonarzy, prebendarza i kapelana oraz cmentarz parafialny ze wszystkimi materiałami zostały sprzedane przez ks. Piotra Józefa Rydulskiego w 1787 r. Józefowi z Janowic
\end{abstract}

* Anna Magiera - mgr historii sztuki, doktorantka w Instytucie Historii, Uniwersytet Papieski Jana Pawła II w Krakowie

e-mail: anulkama@interia.pl

https://orcid.org/0000-0002-2120-1739 
Chwalibogowi, który w tym samym roku zburzył świątynię. Tekst kontraktu sprzedaży między ks. P.J. Rydulskim a J. Chwalibogiem został zamieszczony $\mathrm{w}$ formie aneksu do artykułu.

Słowa kluczowe: Józef z Janowic Chwalibóg; Kazimierz pod Krakowem; kościół św. Jakuba Apostoła Starszego; Michał Jerzy Poniatowski; Piotr Józef Rydulski; Strzemieńczycy

$* * * * *$

Władysław Chotkowski w wydanej ponad sto lat temu książce pt. Księdza Prymasa Poniatowskiego spustoszenie kościelne w Krakowie: przyczynek do dziejów Uniwersytetu ${ }^{1}$ opisał ,rewolucyę kościelną”, jaka dokonała się w drugiej połowie XVIII wieku na terenie całej aglomeracji krakowskiej. W jej obręb zaliczane były oprócz miasta Krakowa, Kazimierza ze Stradomiem i Kleparza także pozostałe przedmieścia oraz wsie. Prezes Komisji Edukacji Narodowej - biskup płocki Michał Jerzy Poniatowski, herbu Ciołek, a od 1784 r. także ostatni prymas I Rzeczypospolitej, podjął szereg działań mających na celu uregulowanie kwestii zbyt dużej liczby zniszczonych i opuszczonych świątyń w diecezji krakowskiej². Cały proces został zapoczątkowany przez decyzję papieża Klemensa XIV z 1773 r. o likwidacji zakonu jezuitów. Poskutkowało to przejęciem majątku pojezuickiego na rzecz Komisji Edukacji Narodowej, kierowanej przez M.J. Poniatowskiego, a tym samym na krakowską wszechnicę. Biskup M.J. Poniatowski dążył do masowych kasat klasztornych na terenie całej diecezji, aby pozyskiwać dalsze fundusze ${ }^{3}$. Wykorzystywał do tego ,,numerus fixus oraz tzw. prawo łaski, które stworzył na własne potrzeby - - . Wszystko to czynił, jak zapewniał, dla dobra oświaty i Akademii Krakowskiej [sic!]"4. Model jego postępowania był zawsze taki sam - spisanie dochodów duchowieństwa z uwzględnieniem uposażenia znajdującego się poza granicami Rzeczypospolitej w wyniku I rozbioru Polski, a następnie na tej podstawie sekularyzacja majątku i sprzedaż budynków poklasztornych. Likwidował kolejne zakony, m.in. benedyktynek, duchaków i duchaczek oraz marków w Krakowie, a także trynitarzy na Kazimierzu ${ }^{5}$. M.J. Poniatowski kontynuował kasacje,

${ }^{1}$ W. Chotkowski, Księdza Prymasa Poniatowskiego spustoszenie kościelne w Krakowie: przyczynek do dziejów Uniwersytetu, Warszawa-Kraków 1918. Warto nadmienić, że prawie trzydzieści lat wcześniej pojawił się artykuł Marii Estreicherówny poświęcony zniesionym kościołom, kolegiatom i klasztorom Krakowa (M. Estreicherówna, Wykaz zniesionych kościołów, kaplic i klasztorów w Krakowie, „Kalendarz Katolicki Krakowski”, 9 (1889) s. 105-119).

${ }^{2}$ Z. Zielińska, Poniatowski Michat Jerzy, w: Polski Stownik Biograficzny (dalej: PSB), t. 27, red. E. Rostworowski, Wrocław-Warszawa-Kraków-Gdańsk-Łódź 1983, s. 455, 457.

${ }^{3} \mathrm{~K}$. Follprecht, Zmiany własności nieruchomości w Krakowie zwiąane z kasatami klasztorów przełomu XVIII i XIX w., „Hereditas Monasteriorum”, 5 (2014) s. 30-31. Tzw. numerus fixus to inaczej oznaczenie stałej liczby zakonnic w klasztorach żeńskich (P.P. Gach, Kasaty zakonów na ziemiach dawnej Rzeczypospolitej i Śląsa 1773-1914, Lublin 1984, s. 22).

${ }^{4}$ K. Karaskiewicz, Prymasa Poniatowskiego potyczki w Akademii Krakowskiej, „Przegląd Historyczny", 88 (1997) nr 1, przypis 49.

${ }^{5}$ Gach, Kasaty zakonów na ziemiach dawnej Rzeczypospolitej i Ślaska 1773-1914, s. 19-22; Follprecht, Zmiany własności nieruchomości w Krakowie związane z kasatami klasztorów przełomu XVIII i XIX w., s. 38-39. 
rozciągając je na przyklasztorne kaplice szpitalne oraz seminaria duchowne. W diecezji było sześć seminariów: trzy w Krakowie, a pozostałe w Kielcach, Lublinie i Sandomierzu. Również tutaj M.J. Poniatowski powoływał się na brak środków finansowych na utrzymanie szkół, a dodatkowo zbyt dużą ich liczbę w diecezji. Seminarium, które miało dalej kształcić alumnów, było wyłącznie krakowskie Seminarium Akademickie ${ }^{6}$. Likwidacji za pontyfikatu M.J. Poniatowskiego uległy także mniejsze kościoły, co spowodowało znaczący spadek liczby obiektów kultu na sakralnej mapie dzisiejszego Krakowa. Jedną ze świątyń trójmiasta - Krakowa, Kazimierza i Kleparza, która nie przetrwała „spustoszeń” z XVIII wieku, był kościół św. Jakuba Apostoła Starszego na krakowskim Kazimierzu?

${ }^{6}$ Chotkowski, Księdza Prymasa Poniatowskiego spustoszenie kościelne w Krakowie, s. 54-55; Karaskiewicz, Prymasa Poniatowskiego potyczki w Akademii Krakowskiej, s. 65.

${ }^{7}$ Stan badań dotyczący nieistniejącego obecnie kościoła św. Jakuba Starszego na krakowskim Kazimierzu nie jest zbyt obszerny. Najistotniejszą, jak dotąd, publikacją jest artykuł Mariana Wolskiego, który stanowi pierwsze i jedyne monograficzne ujęcie tego tematu (tenże, Nie istniejacy kościót pod wezwaniem św. Jakuba Starszego na Kazimierzu, „Rocznik Krakowski”, 61 (1995), s. 11-26). M. Wolski poświęcił kościołowi św. Jakuba również rozdział w swoje książce na temat rodziny Trzecieskich (tenże, Trzeciescy herbu Strzemię. Małopolska rodzina szlachecka XIV-XVI wieku, Kraków 2005). To samo uczynił trzy lata później Tomasz Ściężor, przywołując parafię pw. św. Jakuba jako macierzystą parafię Prokocimia w jednym z rozdziałów swojej publikacji (tenże, Historyczny Prokocim: Monografia wsi podkrakowskiej XIV-XX w., Kraków 2008). Oprócz wspomnianego tekstu W. Chotkowskiego, również Michał Rożek i Magdalena Goras opisali kościół św. Jakuba Apostoła na krakowskim Kazimierzu jako jedną ze świątyń, które zniknęły z mapy Krakowa (M. Rożek, Nie istniejace kościoły Krakowa, „Biuletyn Biblioteki Jagiellońskiej”, 33 (1983) s. 95120; M. Goras, Zaginione gotyckie kościoły Krakowa, Kraków 2003). Zakwalifikowała jednak ona kościół św. Jakuba jako halową świątynię gotycką, zapominając o jego romańskim rodowodzie. Teren kościoła ponadto przebadano archeologicznie. Szczególnie istotne są wydane prace A. Żakiego (tenże, Badania archeologiczne na terenie Krakowa w roku 1956 (seria IV), „Sprawozdania Archeologiczne", 5 (1959) s. 229-236; tenże, Sprawozdanie z badań nad przedlokacyjnym Krakowem w 1957 roku (seria V), „Sprawozdania Archeologiczne”, 15 (1963) s. 329-336; tenże, Badania nad przedlokacyjnym Krakowem w latach 1958-1961 (serie VI-IX), „Sprawozdania Archeologiczne”, 15 (1963) s. 336-351) i Kazimierza Radwańskiego (tenże, Kraków przedlokacyjny: rozwój przestrzenny, Kraków 1975; tenże, Problemy badawcze wczesnośredniowiecznego Krakowa, w: Kraków przedlokacyjny. Materiały sesji naukowej z okazji Dni Krakowa w 1984 roku, Kraków 1987, s. 9-27). Przez szereg kolejnych lat kościół św. Jakuba był wzmiankowany także w licznych przewodnikach po Krakowie i Kazimierzu. Z pierwszych dzieł na ten temat należy wymienić tekst Walerego Eliasza Radzikowskiego (tenże, Kraków dawny i dzisiejszy, Kraków 1902). Na koniec należy wspomnieć także kilka opracowań dotyczących dawnego miasta Kazimierza, w których znajdują się informacje o kościele św. Jakuba. Są to publikacje Wandy Koniecznej (taż, Początki Kazimierza (do r. 1419), w: Studia nad przedmieściami Krakowa, Kraków 1938, s. 7-90), Danuty Rederowej (taż, Studia nad wewnętrznymi dziejami Krakowa porozbiorowego (1796-1809), część I: Zagadnienia urbanistyczne, „Rocznik Krakowski”, 34 (1957) s. 62-177), Stefana Świszczowskiego (tenże, Miasto Kazimierz pod Krakowem, Kraków 1981) i Bogusława Krasnowolskiego (tenże, Ulice i place krakowskiego Kazimierza: z dziejów Chrześcijan i Żydów w Polsce, Kraków 1992; tenże, Lokacje i rozwój Krakowa, Kazimierza i Okołu. Problematyka rozwiąań urbanistycznych, w: Kraków. Nowe studia nad rozwojem miasta, red. J. Wyrozumski, Kraków 2007, s. 355-426; tenże, Krakowski Kazimierz w do- 
W kilku publikacjach, w których wzmiankowany był nieistniejący obecnie kościół św. Jakuba Apostoła, pojawiły się informacje o podwójnym wezwaniu świątyni, gdzie obok św. Jakuba odnotowane jest także wezwanie św. Krzysztofa Męczennika ${ }^{8}$. Wanda Konieczna w jednym z przypisów swojego artykułu krótko skomentowała ów fakt: „Skąd ta wiadomość o drugim patronie - nie wiadomo”. Ponadto pojawia się informacja nie o dwóch wezwaniach, lecz wręcz o dwóch kościołach $^{10}$. Marian Wolski w przypisie wyjaśnia zaistniałą sytuację:

źródła do historii kościoła (...) przekazują konsekwentnie jedno wezwanie: św. Jakuba Starszego, i dopiero akta wizytacji biskupa Załuskiego z 1748 r. podają podwójne wezwanie i historię o dwóch kościołach. (...) Jak można przypuszczać, do tego swoistego uzupełnienia wezwania doszło na przełomie XVII/XVIII w. w wyniku wzrostu znaczenia w strukturze kleru obsługującego kościół prebendarza ołtarza Św. Krzysztofa (...) W świetle źródeł kościół posiadał jedno wezwanie św. Jakuba Apostoła Starszego, a [u Piotra Hiacynta Pruszcza - A.M.] odnotowano tylko zwyczajową jego wersję ${ }^{11}$.

Informację o dwóch kościołach należy odrzucić, chociażby z uwagi na przeprowadzone przez Andrzeja Żakiego badania archeologiczne, w których nie wykazano istnienia fundamentów drugiej świątyni ${ }^{12}$. Oczywiście, choć mało prawdopodobne, mogły się one nie zachować, niemniej jednak jest wręcz niemożliwe, aby na tak niewielkiej przestrzeni istniały obok siebie dwa kościoły. Dużo ciekawsza kwestia dotyczy podwójnego wezwania. Należy zwrócić uwagę, że o śś. Jakubie i Krzysztofie jako równorzędnych patronach świątyni wspomina pod koniec XVIII wieku bp Andrzej Stanisław Kostka Załuski, herbu Junosza ${ }^{13}$. Jest to jedyne źródło, obok wydanego przez P.H. Pruszcza przewodnika, do końca istnienia kościoła św. Jakuba na krakowskim Kazimierzu, w którym zapisano tę informację. Był to ponadto czas, kiedy myśli o przyłączeniu Kazimierza (a także innych okolic, m.in.

bie upadku: od najazdu szwedzkiego (1655-1657) do dzieła Komisji Dobrego Porzadku (1786-1791) i trzeciego rozbioru Polski (1795), „Krzysztofory”, (2009) nr 27, s. 139-158).

${ }^{8}$ E. Ekielski, Miasto Kazimierz i budowle akademickie w tem mieście, Kraków 1869, s. 75; S. Krzyżanowski, Wstęp historyczny, „Rocznik Krakowski”, 6 (1904) s. 2; Świszczowski, Miasto Kazimierz pod Krakowem, s. 141; Katalog zabytków sztuki w Polsce, t. 6: miasto Kraków, cz. 4: Kazimierz, Stradom, Kościoly i klasztory 1, red. I. Rejduch-Samkowa, J. Samek, Warszawa 1994, s. XVI.

${ }^{9}$ Konieczna, Poczatki Kazimierza, s. 12.

${ }^{10}$ P.H. Pruszcz, Kleynoty stotecznego miástá Krakowa, albo koscioły, y co w nich iest widzenia godnego y znácznego, przez Piotra Hiacyntha Prvszcza, krotko opisane, Powtornie záś z pilnośćia przeyźrzáne, y do druku z additámentem nowych Kośćiołow y Relikwii S. podane, z pozwoleniem Zwierzchnośći Duchowney roku pańskiego 1745, Kraków 1861, s. 140; Estreicherówna, Wykaz zniesionych kościołów, kaplic i klasztorów w Krakowie, s. 106; J. Rajman, Średniowieczne patrocinia krakowskie, Kraków 2002, s. 89.

${ }^{11}$ Wolski, Nie istniejący kościót, s. 14.

${ }^{12}$ Żaki, Badania archeologiczne, s. 229-236; tenże, Sprawozdanie z badań, s. 329-336; tenże, Badania nad przedlokacyjnym Krakowem, s. 336-351.

${ }^{13}$ Archiwum Narodowe w Krakowie (dalej: ANK), Akta miasta Kazimierza pod Krakowem, K-887: Visitatio ecclesiae parochialis sancti Jacobi Apostoli Casimiriae ad Cracoviam, die 13 mensis Martii, anni d[omi]ni 1748 (dalej: Wizytacja 1748), s. 1. 
Kleparza) do Krakowa narastały na sile, a granice między jeszcze osobnymi miastami coraz bardziej się zacierały. W Kleparzu istniał od XIV wieku kościół dedykowany również św. Jakubowi (ale Młodszemu) i św. Filipowi (ich wspomnienie przypada na ten sam dzień - 1 maja, stąd powszechną praktyką było obieranie tych dwóch apostołów na patronów jednej świątyni). W momencie, w którym zostałyby przyłączone Kleparz i Kazimierz do Krakowa, wówczas w jednym mieście znajdowałyby się dwa kościoły pod wezwaniem św. Jakuba. Aby zatem jasno odróżniać kościół kazimierski od kleparskiego, należało, choćby zwyczajowo, dodać św. Jakubowi Starszemu wezwanie uzupełniające. Wybór był prosty, gdyż w dzień wspomnienia św. Jakuba - 25 lipca, przypada także w Kościele katolickim pamiątka śmierci św. Krzysztofa. Być może właśnie ta praktyczna potrzeba, zakorzeniona także w ludowej religijności, była powodem, dla którego dawna fara kazimierska zaczęła być podwójnie tytułowana. Niemniej jednak, co należy ostatecznie podkreślić, formalnie kościół nie nosił nigdy podwójnego wezwania.

Zburzony kościół św. Jakuba Starszego znajdował się opodal niewielkiego wzniesienia z wapienia jurajskiego, na południowym zakolu Wisły ${ }^{14}$. Świątynię zbudowano prawdopodobnie na przełomie XI i XII wieku w centrum osady nieznanego obecnie z imienia protoplasty rodu Strzemieni, jako prywatne oratorium $^{15}$. Między drugą połową XII a pierwszą połową XIII wieku w otoczeniu kościoła został założony także cmentarz. Nadmienić należy, że w średniowieczu cmentarze grzebalne powstawały przy kościołach parafialnych (zmarłych grzebano tuż przy murze świątyń, a znaczniejszych wiernych chowano bezpośrednio pod posadzką kościołów) ${ }^{16}$. Stąd też parafia pw. św. Jakuba Starszego, będąca niewątpliwie jedną z najstarszych parafii Kazimierza i Krakowa, musiała powstać najpóźniej już w XIII wieku, mimo że pierwsza wzmianka o farze pochodzi dopiero z 27 lipca 1313 r. i wspomina o Janie - rektorze kościoła ${ }^{17}$. Na okręg parafii pw. św. Jakuba składały się najdawniejsze dobra rodowe Strzemieni, a więc oprócz gruntów wokół kościoła, także liczne podkrakowskie wsie, z których spływały dziesięciny z łanów kmiecych, będące podstawą uposażenia parafii. 27 lutego 1335 r. król Kazimierz Wielki lokował nowe miasto - Kazimierz. Kościół św. Jakuba Starszego znalazł się w obrębie średniowiecznych murów miejskich niedaleko dawnej Bramy Skawińskiej. Na skutek lokacji po 1335 r. część gruntów uposażeniowych została zajęta pod nowo tworzone miasto. W wyznaczonych granicach okręgu parafii znalazły się czwarta część miasta (teren zamknięty od wschodu ul. Krakowską, od północy ul. Piekarską) i jego przedmieścia (domy położone pod murami miejskimi od Podbrzezia do Bramy Skawińskiej, kościół i szpital trędowatych św. Leonarda), a także tereny nad Wisłą. Inne grunty, z któ-

${ }^{14}$ Radwański, Kraków przedlokacyjny, s. 239; Świszczowski, Miasto Kazimierz pod Krakowem, s. 43-44.

${ }^{15}$ Wolski, Trzeciescy, s. 21.

${ }^{16}$ M. Myszka, Dawne cmentarze Krakowa w świetle badań archeologicznych, w: Cmentarz Rakowicki w Krakowie, Kraków 2003, s. 125-126.

${ }^{17}$ Ioannes rector ecclesiae Cracoviensis ad s. Iacobum, w: Kodeks Dyplomatyczny miasta Krakowa 1257-1506, cz. 2-4, wyd. F. K. Piekosiński, Kraków 1882, s. 494, nr CCCLXIX. M. Wolski podaje 1278 r. jako terminus ante quem powstania parafii (tenże, Nie istniejący kościót, s. 16). 
rych płynęły dziesięciny dla kościoła, pozostały odcięte poza murami miasta ${ }^{18}$. Od początku istnienia kościoła parafię obsługiwało dwóch plebanów. Strzemieńczycy posiadali prawo patronatu nad obiema plebaniami. Warto odnotować, że w średniowiecznej Polsce wieloosobowe obsady plebańskie obecne były w ponad dwudziestu parafiach diecezji krakowskiej ${ }^{19}$. Na terenie dzisiejszego Krakowa podwójną plebanię, oprócz omawianej pw. św. Jakuba, posiadała także parafia przy obecnie nieistniejącym kościele Wszystkich Świętych ${ }^{20}$. Jeszcze przed początkiem XV wieku w większości parafii podwójna obsada była likwidowana jako niepraktyczna anomalia, wywołująca niepotrzebne konflikty między duchownymi zarząazającymi parafią. Stąd też podwójne obsady duchownych zamieniane były w prepozytury, czyli kolegia, w skład których wchodził prepozyt i wikariusze wieczyści - mansjonarze ${ }^{21}$. W 1462 r. wystawiono więc dokument reorganizujący strukturę kleru obsługującego świątynię św. Jakuba Starszego na Kazimierzu, znoszący drugą plebanię, a w jej miejsce ustanawiający kolegium mansjonarzy. Pozostałe probostwo, zgodnie z panującą wówczas praktyką, podniesiono do godności prepozytury ${ }^{22}$.

Cezurę czasową niniejszego artykułu wyznaczają dwie daty: 1758 r. (zrzeczenie się praw patronatu wobec parafii przez przedstawicieli rodu Strzemieni) oraz 1787 r. (sprzedaż i zburzenie kościoła), będące zapisem ostatnich lat istnienia kościoła i parafii pw. św. Jakuba Starszego na krakowskim Kazimierzu. W 1758 r. przedstawiciele rodu Strzemieni przenieśli prawa patronatu parafii pw. św. Jakuba na rzecz biskupów krakowskich. Wówczas, od dwóch lat, prepozytem fary był ks. Kazimierz Franciszek Stęplowski (Stemplowski), doktor teologii ${ }^{23}$. W tym samym roku, 10 kwietnia, bp A.S. Kostka Załuski inkorporował probostwo do pre-

${ }^{18}$ Konieczna, Początki Kazimierza, s. 12-14; Wolski, Nie istniejący kościót, s. 12, 17; tenże, Trzeciescy, s. 18-19, 22.

${ }^{19}$ Tematykę podwójnych, potrójnych, a nawet poczwórnych zespołów plebańskich poruszali w swoich artykułach m.in. Tadeusz Lalik (tenże, Zagadnienie ,, vita communis” kapitut polskich XII wieku, w: Wieki średnie. Medium aevum, red. A. Gieysztor, M. Serajski, S. Trawkowski, Warszawa 1962, s. 99-110), Julia Tazbirowa (taż, W sprawie badań nad genezq organizacji parafialnej w Polsce, „Przegląd Historyczny”, 54 (1963) nr 1, s. 85-92), Józef Szymański (tenże, Początki prepozytur $w$ diecezji krakowskiej, „Roczniki Teologiczno-Kanoniczne”, 9 (1962) z. 1, s. 65-76; tenże, Wokót genezy organizacji parafialnej w Polsce, „Przegląd Historyczny”, 55 (1964) nr 3, s. 501-508; tenże, Kanonikat świecki w Małopolsce od końca XI do połowy XIII wieku, Lublin 1995), Eugeniusz Wiśniowski (tenże, Kościót parafialny i jego funkcje społeczne w średniowiecznej Polsce, „Studia Theologica Varsaviensia”, 7 (1969) nr 2, s. 187-237) oraz Bolesław Stanisław Kumor (tenże, Dzieje diecezji krakowskiej do roku 1795, t. 1-4, Kraków 1998-2002).

${ }^{20} \mathrm{~K}$. Walczak, Klejnot miasta zaginiony. Zarys dziejów krakowskiego kościoła Wszystkich Świętych do końca XVI wieku, „Folia Historica Cracoviensia”, 19 (2013) s. 136-139.

${ }^{21}$ Szymański, Wokół genezy, s. 503-504.

${ }^{22}$ Wolski, Nie istniejący kościót, s. 19; tenże, Trzeciescy, s. 19.

${ }^{23}$ Archiwum Kurii Metropolitarnej w Krakowie (dalej: AKMKr), Acta Officialia 188, k. 21. 
fektury krakowskiego Seminarium Akademickiego ${ }^{24}$. Odtąd też świątynia obsadzana była przez profesorów Uniwersytetu Krakowskiego (wówczas Szkoły Głównej Koronnej), a kościół zwyczajowo nazywany był „akademickim”25.

W 1772 r. w wyniku I rozbioru Polski Kazimierz trafił w ręce Austrii na cztery lata. Wojska austriackie stacjonowały na tych terenach do 1776 r., kiedy to wytyczono nową granicę polsko-austriacką opierającą się na korycie Wisły ${ }^{26}$. W rezultacie tego obszar na lewym brzegu rzeki - północny, w tym i Kazimierz, powrócił do Polski, prawy zaś - południowy - u stóp wzgórza Lasoty trafił w ręce władz austriackich, a ci utworzyli tam nowe miasto - Podgórze. Wraz z rozbiorem nastąpił także podział diecezji krakowskiej. Parafie, kolegiaty, opactwa i zakony z tzw. ,galicyjskiej” części diecezji znalazły się początkowo pod zarządem specjalnie utworzonego oficjalatu generalnego z siedzibą w Tarnowie, a potem samego biskupstwa tarnowskiego, powstałego na mocy postanowienia cesarza Józefa II. W oparciu o nowe podziały wiele klasztorów i kościołów utraciło dochody spływające ze wsi dziesięcinnych, a tym samym znaczna część uposażenia duchowieństwa została odcięta od Polski ${ }^{27}$. W granicach Austrii znalazł się także prawie cały okręg parafialny kościoła św. Jakuba Starszego na Kazimierzu. Od Rzeczypospolitej, a tym samym i parafii, odłączone zostały także dziesięciny szlacheckie z folwarków we wsiach spod Bochni (Łysokanie, Czyżów, Zborczyce, Surówki), Zakliczyna nad Dunajcem (Janowice Dolne i Górne, Wróblowice Dolne i Górne, Bieńkowice, Lichwin) oraz podkrakowskich (Swoszowice, Wróblowice, Strzałkowice, Kurdwanów, Wola - obecnie Wola Duchacka). Z tych ostatnich dodatkowo przestały płynąć dziesięciny z ról kmiecych ${ }^{28}$. Kościół pozostał zatem z niewielką liczbą wiernych i ubogim uposażeniem, na który składała się „parafia podgórska, z wyjątkiem Rybaków, po tamtej stronie Ludwinowa i Zakrzówka, które należały do parafii ks. ks. Paulinów na Skałce - i wieś Płaszów po tamtej stronie Wisły, nim nowe koryto było wyrżnięte" 29 . Ponadto z czynszami z miasta Kazimierza, a więc terenami „oprócz ulicy Krakowskiej - Nadwiśla - Podbrzezia - pół ulicy Skawińskiej - ulicy Wawrzenieckiej”’30. Były to jednak niewystar-

${ }^{24}$ Biblioteka Jagiellońska (dalej: BJ), Summaryusz praw y dokumentow koscioła farnego swiętego Jakoba Apostoła na Kazimierzu przy Krakowie, rkp 1061, brak foliacji i paginacji, zapis n[umer]o 4 to z $1758 \mathrm{r}$.

${ }^{25}$ Chotkowski, Księdza Prymasa Poniatowskiego spustoszenie kościelne w Krakowie, s. 133; Rederowa, Studia, s. 151.

${ }^{26}$ Krasnowolski, Krakowski Kazimierz, s. 151.

${ }^{27}$ Kumor, Granice (archi)diecezji krakowskiej (1000-1939), „Prawo Kanoniczne: kwartalnik prawno-historyczny", 6 (1963) z. 1-4, s. 545; Gach, Kasaty zakonów na ziemiach dawnej Rzeczypospolitej i Ślaska 1773-1914, s. 18-20.

${ }^{28}$ Wolski, Nie istniejący kościót, s. 17; tenże, Trzeciescy, s. 19-21.

${ }^{29} \mathrm{~W}$ źródle błędnie wieś Płaszów zaliczona została do uposażenia parafii pw. św. Wawrzyńca we wsi Bawół (obok kościoła św. Jakuba i św. Michała na Skałce trzeciej najstarszej świątyni kazimierskiej). Autor nie był jednak pewien, gdyż dodał stwierdzenie ,a może i wieś Płaszów” (Archiwum Klasztoru Kanoników Regularnych Laterańskich w Krakowie (dalej: AKKRL), Historya ks. ks. Kanoników Regularnych Lateraneńskich w Polsce od roku 1750 do r. 1857 wyjęta z pamiętników ks. Piotra Studentowicza, członka Zgromadzenia krakowskiego, b. sygn., s. 9).

${ }^{30}$ Tamże, s. 10. 
czające dochody, aby utrzymać parafię na dotychczasowym poziomie. W tym samym roku, co I rozbiór Polski - 21 maja 1772 r. - zmarł ks. K.F. Stęplowski. W swoim testamencie przekazał Seminarium Akademickiemu, w którym mieszkał, zbiór ksiąg pochodzących z biblioteki kościoła św. Jakuba Starszego na Kazimierzu ${ }^{31}$. Jego następcą został ks. Antoni Józef Żołędziowski, doktor teologii. Był on ostatnim prepozytem parafii. Złożył rezygnację z urzędu 26 maja $1783 \mathrm{r}$., na kilka miesięcy przed swoją śmiercią w dniu 24 lipca 1783 r. ${ }^{32}$

Znacznie ograniczony obszar parafii, mała liczba wiernych, brak dostatecznych funduszy na utrzymanie fary oraz rezygnacja prepozyta - wszystko to doprowadziło do ostatecznego upadku parafii pw. św. Jakuba Starszego na Kazimierzu. Probostwo zostało zniesione 28 maja 1783 r., a komendarzem św. Jakuba został ks. Piotr Józef Rydulski, proboszcz parafii pw. św. Szczepana w Krakowie $^{33}$. Jeszcze 16 czerwca 1783 r. wpłynęła do prezydenta miasta Kazimierza Jana Bekierskiego skarga pospólstwa miasta Kazimierza na przedsiębiorcę Jana Okońskiego, który zagarnął tereny przylegające z jednej strony do murów miejskich, a od zachodu do cmentarza przy kościele św. Jakuba i ogrodził je tak, że mieszkańcy musieli przechodzić przez cmentarz, aby dojść do swoich domów ${ }^{34}$. Parafię pw. św. Jakuba ostatecznie zniesiono 9 lipca 1783 r., a czynności tej dokonał ks. P.J. Rydulski ${ }^{35}$. Po likwidacji wierni, to jest 301 osób, zostali objęci opieką duszpasterską parafii pw. Bożego Ciała (mieszkańcy Kazimierza i części wsi Beszcz tereny dzisiejszego Dąbia - między Starą a Nową Wisłą) oraz parafii pw. św. Mikołaja (mieszkańcy wsi Beszcz, na północ od koryta Wisły). Od teraz dziesięciny miały spływać do tych parafii, zgodnie $\mathrm{z}$ wytyczonym podziałem ${ }^{36}$. Jeśli chodzi o wyposażenie kościoła św. Jakuba, niestety zachowane źródła nie pozwalają w pełni odpowiedzieć na pytanie, gdzie zostały przekazane elementy wystroju: „gdzie się dzwony, organy, ołtarze i ubiory kościelne dostały wcale nie jest wiadomo"37. Choć ich dysponentem został ks. P.J. Rydulski, jako komendarz dawnej parafii pw. św. Jakuba i administrator jej majątku, to jednak nie przetrwały one

${ }^{31}$ W. Baczkowska, Stęplowski (Stemplowski) Kazimierz Franciszek, w: PSB, t. 43, red. E. Rostworowski, Warszawa-Kraków 2004, s. 539.

${ }^{32}$ AKMKr, Acta Episcopalia (dalej: AEp) 113, k. 33v-34; J. Wysocki, Żołędzikowski Antoni Józef, w: Stownik polskich teologów katolickich, red. H.E. Wyczawski, t. 4, Warszawa 1983, s. 554; Wolski, Nie istniejący kościót, s. 19.

${ }^{33}$ BJ, Teki Żegoty Paulego, Notaty luźne do historii m. Krakowa i okolicy: wypisane z akt grodzkich, miejskich i kapitulnych krakowskich. T. 7, Acta consularia i acta scabinalia Casimiriensia (dalej: TŻP 7), rkp 5357, k. 114.

${ }^{34}$ Tamże, k. 112.

${ }^{35}$ Chotkowski, Księdza Prymasa Poniatowskiego spustoszenie kościelne w Krakowie, s. 132. W literaturze pojawia się także odosobniona zbiorcza data 1790 r., kiedy to „zniszczono parafię i kościół" (Świszczowski, Miasto Kazimierz pod Krakowem, s. 256), a także całkowicie błędna data, gdzie 1783 r. uznano za moment wzniesienia kościoła. Choć nie można wykluczyć, że była to po prostu omyłka pisarska i zamiast „zniesiony” zostało zapisane „wzniesiony” (C. Franciszek, Przewodnik abo kościołów krakowskich krótkie opisanie wydany w 1603 z widokami Krakowa, którego już nie ma, oprac. J. Kiliańczyk-Zięba, Kraków 2002, s. 159).

${ }^{36}$ Chotkowski, Księdza Prymasa Poniatowskiego spustoszenie kościelne w Krakowie, s. 134.

${ }^{37}$ AKKRL, Historya, s. 10. 
w kościele św. Szczepana ${ }^{38}$. P.J. Rydulski otrzymał zgodę na sprzedaż sreber kościelnych. Uzyskaną sumę (22 998 złotych polskich 27 groszy) przeznaczył na naprawę zarządzanego przez siebie kościoła św. Szczepana ${ }^{39}$. Część nieruchomości i paramentów liturgicznych została wystawiona na sprzedaż, a dochody z niej przekazane parafii pw. śś. Piotra i Pawła na Garbarach, filii św. Szczepana ${ }^{40}$. Z kolei wiadomo, że księgi metrykalne po kościele św. Jakuba Starszego trafiły do kościoła Bożego Ciała ${ }^{41}$, gdzie znalazły się także niektóre epitafia ze świątyni jakubowej, jednak tam zaginęły ${ }^{42}$. Być może pozostałe nieruchomości i ruchomości zostały wyrzucone jako zbyteczne przy rozbiórce albo potem - jako poniszczone lub uszkodzone. Niestety nie sposób dziś tego ustalić.

Dnia 20 lutego 1787 r. rozpoczęła na Kazimierzu działalność Komisja Dobrego Porządku, której przewodniczył referendarz wielki koronny i kanonik krakowski ks. Tymoteusz Gorzeński, herbu Nałęcz. Celem komisji był nadzór nad zabudową przestrzenną miasta oraz uporządkowanie Kazimierza po stacjonujących tu wojskach austriackich. Wówczas postanowiono zająć się także niszczejącymi terenami po zlikwidowanych parafiach, w tym i św. Jakuba Starszego, która została skasowana przed czterema laty ${ }^{43}$. Również w 1787 r., na skutek skarg części rajców miejskich z 11 stycznia 1787 r., Komisja oskarżyła Szymona Rotkiewicza, zięcia J. Okońskiego, o rozbiórkę baszty przy kościele św. Jakuba i kradzież materiałów oraz murów świątyni. Te, jak i inne winy zostały mu udowodnione przed sądem $^{44}$.

Dnia 2 kwietnia 1787 r. bp M.J. Poniatowski, jako administrator diecezji krakowskiej, wydał oficjalną zgodę, aby w efekcie postanowień Komisji sprzedać tereny po niszczejącym kościele św. Jakuba Starszego na Kazimierzu osobom mogącym je zagospodarować ${ }^{45}$. Cztery dni później ks. P.J. Rydulski zawarł więc umowę z Józefem z Janowic Chwalibogiem, sędzią sejmowym i wojskim więk-

${ }^{38}$ Należy nadmienić, że dawna parafia pw. św. Szczepana na Placu Szczepańskim istniała do 1801 r. Jej wyposażenie zostało rozproszone po innych kościołach lub sprzedane na licytacjach. W czasie rozmów odbytych w obecnej parafii pw. św. Szczepana przy ul. Henryka Sienkiewicza autorce udało się ustalić, iż żaden element wyposażenia nie trafił tutaj, lecz rzekomo znalazły się one w posiadaniu Klasztoru OO. Karmelitów w Krakowie na Piasku. Po skontaktowaniu się z Archiwistą Klasztoru autorka otrzymała informację, że w zasobie nie ma wyposażenia z kościoła św. Szczepana ani choćby archiwaliów na ich temat. Jedyna informacja dotycząca kościołów na Kazimierzu, która znajduje się w Archiwum Klasztoru, dotyczy cegieł ze zburzonego kościoła św. Wawrzyńca ze wsi Bawół, z których bracia zakonni zbudowali figarnię w ogrodzie.

${ }^{39}$ Chotkowski, Księdza Prymasa Poniatowskiego spustoszenie kościelne w Krakowie, s. 132.

${ }^{40}$ AKMKr, AEp. 118, s. 186-218; Chotkowski, Księdza Prymasa Poniatowskiego spustoszenie kościelne w Krakowie, s. 135; Wolski, Nie istniejący kościót, s. 24.

${ }^{41}$ W AKKRL przechowywane są Księgi Metrykalne z parafii pw. św. Jakuba Starszego na Kazimierzu z następujących lat: 1597-1621, 1708-1710, 1717-1734, 1756, 1758-1772.

${ }^{42}$ AKKRL, Historya, s. 10; Ściężor, Historyczny Prokocim, s. 170.

${ }^{43}$ BJ, Teki Żegoty Paulego, Notaty luźne do historii m. Krakowa i okolicy: wypisane z akt grodzkich, miejskich i kapitulnych krakowskich. T. 10, Katedra, kościoły, klasztory w Krakowie i na Kazimierzu (dalej: TŻP 10), rkp 5357, k. 202v.

${ }^{44}$ BJ, TŻP 7, k. 95; Krasnowolski, Krakowski Kazimierz, s. 152-154.

${ }^{45}$ BJ, TŻP 7, k. 114. 
szym krakowskim, na sprzedaż terenów pokościelnych: murów budowli (ze zgodą na rozbiórkę kościoła), ogrodu, domów proboszcza, księży mansjonarzy, prebendarza i kapelana oraz cmentarza parafialnego ze wszystkimi materiałami ${ }^{46}$. J. Chwalibóg otrzymał także grunty wchodzące w skład dawnego uposażenia parafii nad Wisłą - folwark na Podbrzeziu oraz łąkę przy murach miejskich za Bramą Bocheńską. Całość została zakupiona za kwotę 17000 złp, która została ulokowana na procent na dobrach Zbigały. Umowa opiewała jednak na łączną sumę 18000 złp. Owe brakujące 1000 złp to kapitał posiadany przez parafię pw. św. Jakuba, który był własnością dawnego Arcybractwa Niepokalanego Poczęcia Najświętszej Marii Panny lokowany w 1723 r. na dobrach Łatanice ${ }^{47}$. Archikonfraternię ufundował w 1629 r. ks. Jan Olchawski, kanonik opatowski i prepozyt św. Jakuba. W 1630 r. bp Marcin Szyszkowski erygował Arcybractwo Niepokalanego Poczęcia NMP przy kościele na Kazimierzu. Miało ono swoją własną kaplicę bracką, w której znajdował się łaskami słynący obraz Matki Bożej z Dzieciątkiem Jezus na ręce. Tam też, wokół obrazu, znajdowały się liczne wota, zawieszone na znak otrzymanych łask. Co stało się z tym obrazem, obecnie nie wiadomo. Arcybractwo istniało, tak jak parafia, do 1783 r., kiedy zostało skasowane, a jego uposażenie znalazło się w rękach proboszcza kościoła św. Szczepana w Krakowie, wspomnianego ks. P.J. Rydulskiego ${ }^{48}$. W umowie zawarto także polecenie, aby na miejscu cmentarza postawiona została figura lub kapliczka dla upamiętnienia tego miejsca ${ }^{49}$. W maju 1787 r. J. Chwalibóg rozebrał kościół św. Jakuba Apostoła na Kazimierzu i przeznaczył go na materiał budowlany ${ }^{50}$. Po wyburzeniu kościoła, ogrodu i cmentarza powstały puste place nad Wisłą, na których postawione zostały murowane domy oznaczone numerami 36 i 37 przy ul. św. Jakuba „Większej”

${ }^{46}$ Pełna treść kontraktu znajduje się w aneksie.

${ }^{47}$ Latanice - dziś Łatanice, wieś w powiecie wiślickim, oddalona ok. 7 km od Buska-Zdroju i 8 km od Wiślicy, parafia pw. św. Bartłomieja Apostoła w Chotlu Czerwonym (Chotel Czerwony, w: Stownik geograficzny Królestwa Polskiego i innych krajów słowiańskich (dalej: SGKP), red. F. Sulimierski, B. Chlebowski, W. Walewski, t. 1, Warszawa 1880, s. 637-638; Eatanice, w: SGKP, red. F. Sulimierski, B. Chlebowski, W. Walewski, t. 5, Warszawa 1884, s. 608).

${ }^{48}$ ANK, Wizytacja 1748, s. 21-27; W.A. Maciejowski, Polska aż do pierwszej połowy XVII wieku pod względem obyczajów i zwyczajów w czterech częściach opisana, t. 1, Petersburg-Warszawa 1842, s. 327-328; Pruszcz, Kleynoty stołecznego miástá Krakowa, s. 140-141; Chotkowski, Księdza Prymasa Poniatowskiego spustoszenie kościelne w Krakowie, s. 133; Wolski, Nie istniejący kościót, s. 23.

${ }^{49} \mathrm{Na}$ obecnym etapie badań nie udało się odnaleźć ani w literaturze, ani w źródłach informacji, która mogłaby potwierdzić, że wspomniana figura bądź kapliczka rzeczywiście stanęła na tym miejscu. Wnioskować należy, że skoro również cmentarz został zburzony w maju 1787 r., to owo miejsce upamiętnienia nigdy nie powstało.

${ }^{50}$ Rok 1787 wzmiankowany jest w źródłach i literaturze (BJ, TŻP 10, k. 202v; Radzikowski, Kraków dawny i dzisiejszy, s. 219; Radwański, Kraków przedlokacyjny, s. 239; Rożek, Nie istniejące kościoły, s. 118; Wolski, Nie istniejący kościót, s. 24). Z kolei S. Świszczowski przesunął datę zniszczenia kościoła na 1790 r. (tenże, Miasto Kazimierz pod Krakowem, s. 256), a C. Franciszek na lata 1795-1809 (tenże, Przewodnik, s. 159). 
(obecnie ul. Skawińskiej) dla J. Chwaliboga i jego żony Pelagii Zborowskiej oraz pięciorga dzieci ${ }^{51}$.

We wschodniej części terenu zakupionego przez J. Chwaliboga postawiono cegielnię wraz z kamienicą jednopiętrową, gdyż poza granicami Rzeczypospolitej, na skutek regulacji rozbiorowej, znalazła się istniejąca wcześniej cegielnia stojąca obok drogi do Wieliczki ${ }^{52}$. W literaturze obecna jest także informacja o założonym tutaj wapienniku (nadmienić należy, że w ręce austriackie dostały się również Krzemionki, z których pozyskiwano kamień, a więc potrzebowano i takiego miejsca na Kazimierzu). Prawdopodobnie to wapiennik zniszczył niewielkie skaliste wzniesienie, na którym postawiony był kościół św. Jakuba ${ }^{53}$. Nie można wykluczyć także, że część lub całość kamieni z rozebranego kościoła św. Jakuba również została wówczas wykorzystana do produkcji wapna. Jednak czy ów wapiennik powstał przed wzniesieniem cegielni, czy też po, albo kto był jego właścicielem, nie sposób jednoznacznie rozstrzygnaćc ${ }^{54}$. Być może słuszne wydaje się postawienie hipotezy, że jednak cegielnia została wzniesiona jako pierwsza, a wapiennik jako drugi z trzech powodów. Po pierwsze dlatego, że ks. Piotr Kazimierz Studentowicz ${ }^{55}$, członek krakowskiego Zgromadzenia Kanoników Regular-

${ }^{51}$ BJ, Wykaz domów miasta Krakowa wraz z zmiana ich właścicieli od r. 1790 do r. 1846 przez Konstantego Fijałkowskiego, urzędnika W[olnego] M[iasta] Kr[akowa] sporzadzony, rkp 2580, k. 46v-47; Herbarz Polski, cz. 1: Wiadomości historyczno-genealogiczne o rodach szlacheckich, t. 3, wyd. A. Boniecki, Warszawa 1900, s. 128.

${ }^{52}$ Kazimierska zabudowa zwana była „na Krajewskiem w cegielni”, albowiem obywatel Kazimierz Krajewski (Krajowski) zarządzał nią. Nie wiadomo, czy zakupił teren pod cegielnię, czy tylko go wydzierżawił (AKKRL, Historya, s. 9-10; BJ, Wykaz domów, k. 47).

${ }^{53}$ Rederowa, Studia, s. 151; Radwański, Kraków przedlokacyjny, s. 239; Świszczowski, Miasto Kazimierz pod Krakowem, s. 255; Radwański, Problemy badawcze, s. 22.

${ }^{54}$ Kolejność: najpierw cegielnia, a potem wapiennik (Rederowa, Studia, s. 151; Radwański, Kraków przedlokacyjny, s. 239; Krasnowolski, Ulice i place, s. 138), najpierw wapiennik, a potem cegielnia (Krasnowolski, Krakowski Kazimierz, s.155). Pojawia się także informacja zbiorcza niedefiniująca, co było pierwsze, a więc „wapiennik i cegielnia” (Ekielski, Miasto Kazimierz, s. 78, przypis 3; Estreicherówna, Wykaz zniesionych kościołów, kaplic i klasztorów w Krakowie, s. 106; S. Tomkowicz, Ulice i place Krakowa w ciagu dziejów. Ich nazwy i zmiany postaci, seria Biblioteka Krakowska, nr 63-64, Kraków 1926, s. 222). Przy tej okazji trzeba wspomnieć także osamotnione zdanie S. Świszczowskiego, który stwierdził, że nowe wapiennik i cegielnia powstały w „sąsiedztwie opuszczonego widocznie kościoła św. Jakuba”, który dopiero „w roku 1790 zniszczono”, a więc zadatował je przed zburzeniem kościoła (tenże, Miasto Kazimierz pod Krakowem, s. 255256). Jeżeli zaś sprawa tyczy się właściciela wapiennika, to E. Ekielski stwierdził, że piece wapienne były w posiadaniu Wolfa Schönberga (tenże, Miasto Kazimierz, s. 78, przypis 3). Informację tę potwierdza M. Estreicherówna (taż, Wykaz zniesionych kościołów, kaplic i klasztorów w Krakowie, s. 106). S. Świszczowski jako właściciela cegielni i wapiennika wskazał Kazimierza Krajewskiego (tenże, Miasto Kazimierz pod Krakowem, s. 255). Z kolei B. Krasnowolski wspomniał, że w 1794 r. K. Krajowski utworzył tu cegielnię, a potem teren ten został zakupiony przez Icka i Gutę Schönbergów, którzy założyli tu wapiennik (tenże, Ulice i place, s. 138). W swoim artykule opublikowanym w 2009 r. stwierdził, że jednak K. Krajewski był właścicielem wapiennika i założył go w 1794 r., a potem zaś cegielnię (tenże, Krakowski Kazimierz, s. 155).

${ }^{55}$ Piotr Kazimierz Studentowicz (1797-1870) - był jednym z krakowskich zakonników, który sprawiał liczne kłopoty. Jego publiczne ekscesy, nierząd z cudzą żoną, skłonności do pijaństwa i kra- 
nych Laterańskich, w swoich pamiętnikach opisał losy kościoła św. Jakuba zaraz po zburzeniu i wymienił tam bezpośrednie wzniesienie cegielni K. Krajewskiego, nic nie pisząc o wapienniku. Ponadto poznał go osobiście, o czym wspomniał: „Ten obywatel podał [różnego rodzaju informacje] za żywota piszącemu tę kronikę" 56 . Gdyby zatem przed cegielnią istniał tu wapiennik, to $\mathrm{z}$,kronikarskiego obowiązku" autor zapewne by to odnotował. Drugi argument przemawiający za postawioną tu tezą odnosi się do 1804 r. Otóż 29 kwietnia 1804 r. umarł J. Chwalibóg, pierwszy właściciel terenów po kościele św. Jakuba Apostoła na krakowskim Kazimierzu ${ }^{57}$. Już we wrześniu 1804 r. na łamach „Gazety Krakowskiej” zamieszczone zostało ogłoszenie o wystawieniu na sprzedaż dwukondygnacyjnego domu rodzinnego Chwalibogów pod nr. 36 i 37 oraz przylegających doń oficyny, stajni, wozowni, cegielni z ,porządnemi” szopami, dwukondygnacyjnego spichlerza oraz ogrodu. Wiadomość została zamieszczona prawdopodobnie przez wdowę po J. Chwalibogu lub jedną z jego córek, o czym świadczy informacja końcowa: „o cenie dowiedzieć się każdego czasu można na mieyscu u właścicielki" ${ }^{58}$. W ogłoszeniu pojawia się informacja o cegielni, lecz znów ani słowa o wapienniku. Być może to już nowy właściciel zakupił te tereny i po 1804 r. założył wapiennik. Po trzecie Eustachy Ekielski w swojej książce Miasto Kazimierz i budowle akademickie $w$ tem mieście wspomina, że w czasach mu współczesnych, a więc najpóźniej w drugiej połowie XIX wieku, istniały nadal na Kazimierzu piece wapienne, co może prowadzić do wniosku, iż powstały później niż cegielnia $^{59}$.

Na koniec poruszyć należy jeszcze jedną kwestię, a mianowicie, czy mimo upływu czasu, rozbiórki na materiały, powstania cegielni i wapiennika, które - jak już wspomniano - uszkodziły wapienną skałę tego terenu, pozostały jakieś materialne ślady archeologiczne po nieistniejącym obecnie kościele św. Jakuba Starszego na krakowskim Kazimierzu? Już po wojnie, w latach 50. XX wieku A. Żaki wraz z zespołem archeologów prowadził badania na terenie ul. Małgorzaty Fornalskiej 7 i 9 (obecnie ul. Hieronima Wietora), gdzie jeszcze do 1787 r. istniał kościół św. Jakuba. Wówczas odkryto ceramikę z okresu lateńskiego i rzymskiego oraz kabłączek skroniowy, ceramikę wczesnośredniowieczną i kilkadziesiąt szkieletów z terenów dawnego cmentarza. Co ciekawsze, odkopano wówczas fragment fundamentu półkolistej w rzucie absydy kościoła z ciosów piaskowca oraz przyparte do niego ceglane ścianki barokowego grobowca. Stwierdzono wówczas, że

dzieży zmuszały kilkakrotnie władze klasztoru Kanoników Regularnych do umieszczenia ks. P.K. Studentowicza w domach poprawy dla duchownych. W związku z tym nie ma pewności, że to on rzeczywiście był autorem całej kroniki, a nie jedynie pamiętników, na podstawie których została ona spisana (K. Latak, Kongregacja krakowska kanoników regularnych laterańskich na przestrzeni dziejów, Kraków 2002, s. 47, 63, 285).

${ }^{56}$ AKKRL, Historya, s. 10.

${ }^{57}$ J. Chwalibóg zmarł na apopleksję w wieku siedemdziesięciu dwóch lat w swoim domu na Kazimierzu (AKKRL, Liber mortuorum in parochia S[ancti]s[imi] Corporis Christi Casimiriae ad Cracoviam ab anno 1797 ad annum 1812. Tomus I, I-A-1, s. 92).

${ }^{58}$ „Gazeta Krakowska” z niedzieli 30 września 1804 r., dodatek nr 79, s. 943.

${ }^{59}$ Ekielski, Miasto Kazimierz, s. 78, przypis 3. 
w odsłoniętych resztkach mury kościoła nie posiadają wątku romańskiego ani śladów murów ceglanych. Fundament zapewne nie miał wątku kamiennego charakterystycznego dla romanizmu, który występował w murze partii nadziemnych. Odkryto także fundamenty budowli o charakterze mieszkalnym, zapewne domów proboszcza, mansjonarzy, prebendarza i kapelana oraz ślady cegielni ${ }^{60}$.

Po dawnych zabudowaniach kościelnych do 1936 r. ostał się tylko budynek mieszczący plebanię parafialną, znajdujący się przy ul. Skawińskiej $16^{61}$. Współcześnie, w XX wieku wzniesiono na tym terenie kamienice mieszkalne oraz założono plac zabaw i alejki na Bulwarze Kurlandzkim nad Wisłą.

Podsumowując, w powyższym artykule zaprezentowano ostatnie lata funkcjonowania średniowiecznego kościoła św. Jakuba Apostoła Starszego na krakowskim Kazimierzu, którego historia jest nadal w literaturze naukowej dość mało znana. Jak dotąd kazimierski kościół pozostawał w cieniu kościoła śś. Michała Archanioła i Stanisława na Skałce, gdzie co roku w maju odbywają się obchody związane z pamiątką śmierci św. Stanisława ze Szczepanowa. Na swoiste zapomnienie dawnej fary miejskiej miały również wpływ zakładane na Kazimierzu klasztory: Kanoników Regularnych Laterańskich i Augustianów Eremitów skupione przy świątyniach pw. Bożego Ciała oraz śś. Katarzyny Aleksandryjskiej i Małgorzaty, także mające średniowieczne korzenie. Niewykluczone, że zburzenie kościoła św. Jakuba pod koniec XVIII wieku dokonane wskutek reform bp. M.J. Poniatowskiego, a w ślad za tym zniknięcie materialnych śladów świątyni z mapy miasta, spowodowało, że badacze przez lata poświęcali uwagę w swoich artykułach i książkach głównie istniejącym kościołom Kazimierza. Zachowały się jednak źródła, z których można poznać dzieje kościoła i parafii pw. św. Jakuba Starszego na Kazimierzu w latach 1757-1787, a także pozwolić sobie na postawienie kilku hipotez na temat dalszych losów tej części miasta aż do 1804 r. Szczególnie cenny okazał się, odnaleziony w Archiwum Uniwersytetu Jagiellońskiego, kontrakt zawarty między ks. P.J. Rydulskim a J. Chwalibogiem, który dotyczył sprzedaży dóbr po dawnym kościele w 1787 r. Edycja źródłowa tego dokumentu, stanowiąca symboliczne zamknięcie historii kościoła św. Jakuba, prezentowana jest $\mathrm{w}$ aneksie.

\section{$* * * * *$}

Tekst XVIII-wiecznego źródła poddano modernizacji, opierając się na Instrukcji wydawniczej dla źródet historycznych od XVI w. do połowy XIX wieku ${ }^{62}$. W tekście część skrótów zastosowanych przez skrybę rozwinięto. Pozostawiono jednak w formie skróconej ,jw”, „imć”, „s. Jakub” itp., zamieniając jednak literę ,s" na ,ś".

${ }^{60}$ Żaki, Badania archeologiczne, s. 230-233; tenże, Archeologia Małopolski wczesnośredniowiecznej, Kraków 1974, s. 530, 540; Świszczowski, Miasto Kazimierz pod Krakowem, s. 44.

${ }^{61}$ M. Rożek, Przewodnik po zabytkach i kulturze Krakowa, Kraków 1997, s. 432; Ściężor, Historyczny Prokocim, s. 168.

${ }^{62}$ Instrukcja wydawnicza dla źródet historycznych od XVI do połowy XIX wieku, red. K. Lepszy, Warszawa 1953. 
Dodano stosowne znaki diakrytyczne i interpunkcyjne, a także przy nazwach własnych miast, ziem i jednostek terytorialnych zapisano je wielką literą. Uwzględniono współczesne zasady ortograficzne, np. w słowach „puł” na „pół” lub „sprzedarzy” na „sprzedaży”, zasady pisowni przedrostka w słowie „ztamtąd” na „stamtąd”, a także zasady pisowni rozdzielnej, np. we frazach „niedopełnił” na „nie dopełnił” lub „niemogł” na „nie mógł”. Postarano się zmodernizować pisownię dla większej czytelności tekstu, stąd też zamieniono w poszczególnych słowach pojedyncze litery: „y” na ,j” (słowo „niemniey” zamieniono na „niemniej”), „," na ,," (,kancellaryi” na „kancelarii”), ,y” na „,e” (,napotym” na „na potem”), i” na ,„” (,,iedney” na ,jednej”), ,e” na „y” (,zostającemi” na ,zostającymi”), „," na ,"i” (,wszystkiemi” na „wszystkimi”), ,z” na „s” (,tranzakcja” na „transakcja”), „,x” na „ks” (,xiędzem” na „księdzem”), „dz” na „,́c” (,bydz” na „być”). W słowach tego wymagających podwójny zapis liter „,ss”, „ll”, „mm” został zamieniony na pojedynczy, przykładem mogą być tutaj takie słowa jak: ,,possesye”, ,possessorowie”, „sukcessorowie”, „,intromissji”, „kollegiata”, „kancellaryia”, „summa”, „kommendarz”.

Przypisy dotyczące edycji tekstu źródła oraz terminologiczne zawierające biogramy wspomnianych w umowie osób, a także objaśniające stosowne pojęcia zostały zapisane kursywą dla rozróżnienia komentarzy od narracji źródła, zapisanego antykwą. Nadmienić trzeba, że źródłu pierwotnie nie została nadana przez archiwistów ani foliacja, ani paginacja. Stąd też dodano numery stron, na których znajdują się poszczególne partie tekstu. Je również zapisano kursywą i dodatkowo ujęto w nawiasy kwadratowe. Nieliczne wtręty z języka łacińskiego postanowiono pozostawić bez tłumaczenia ich w tekście głównym.

\section{ANEKS}

Kraków, 6 kwietnia 1787 r.

Kontrakt między ks. Piotrem Rydulskim a Józefem z Janowic Chwalibogiem dotyczacy sprzedaży gruntów, ogrodów i budynków po kościele św. Jakuba Apostoła Starszego na krakowskim Kazimierzu

Oryginal: Archiwum Uniwersytetu Jagiellońskiego, dokument pergaminowy, 5164, pergamin; odbita okrągła pieczęć z orłem w koronie i napisem „1 GR[OSZ]. SR[EBRNY]".

Kopia: brak

Wydanie: brak

Wzmianka: Władysław Chotkowski, Księdza Prymasa Poniatowskiego spustoszenie kościelne w Krakowie: przyczynek do dziejów Uniwersytetu, Warszawa-Kraków 1918, s. 133. 
[s. 1] Między w[ielmo]żnym imć księdzem Piotrem Rydulskim ${ }^{63}$, kanclerzem kolegiaty ś. Anny, proboszczem kościoła ś. Szczepana ${ }^{64}$ w Krakowie, rządcą Seminarium Akademickiego Krakowskiego, niemniej komendarzem ${ }^{65}$ kościoła i resztujących prowentów fary ś. Jakuba na Kazimierzu przy Krakowie będącego z jednej, a jw imć panem Józefem z Janowic Chwalibogiem ${ }^{66}$, sędzią sejmowym, wojskim wyższym w[ojewó]dztwa krak[owskiego] z drugiej strony, stawa takowa

${ }^{63}$ Piotr Józef Jan Kanty Rydulski (1735-1789) - syn Jakuba, doktor teologii, profesor Uniwersytetu Krakowskiego (wyktadowca na Wydziale Filozoficznym) i zwolennik reform Hugona Kołłataja. Duchowny katolicki podobnie jak jego starszy brat Dominik Jan Rydulski. Senior szkoły św. Floriana w Krakowie, kanonik kolegiaty Wszystkich Świętych, kanclerz kolegiaty św. Anny, a także proboszcz kościoła św. Szczepana. Przyczynit się do odnowienia świątyni św. Szczepana w 1788 r., wystawiajac nowy oltarz i marmurowa posadzkę (Baczkowska, Rydulski Piotr Józef Jan Kanty, w: PSB, t. 33, red. H. Markiewicz, Wrocław-Warszawa-Kraków 1991-1992, s. 428-429; J. Szczepaniak, Spis prałatów i kanoników kapituly katedralnej oraz kapituł kolegiackich diecezji krakowskiej XVIII w., Kraków 2008, s. 97, 100, 110; tenże, Nekrologium. Księża diecezji krakowskiej zmarli w latach 1749-1810, Kraków 2010, s. 167).

${ }^{64}$ Nieistniejący obecnie kościót św. Szczepana w Krakowie - kościót wzniesiony zapewne $w$ pierwszej połowie XIII wieku w obrębie ścisłego centrum miejskiego, na terenach dzisiejszego Placu Szczepańskiego, który swa nazwę zawdzięcza właśnie zburzonej światyni. Światynia orientowana, trójnawowa z prostokąnym prezbiterium. Kościót pod patronatem królewskim aż do końca XVI wieku, kiedy to biskup krakowski Piotr Myszkowski ofiarowat go dla zakonu jezuitów. Wokresie baroku w kościele powstało mauzoleum rodowe rodziny Korycińskich, herbu Topór. W 1732 r. kościót św. Szczepana zostat odebrany jezuitom i wszedt pod patronat Uniwersytetu Krakowskiego, sześćdziesiąt pięć lat później zaś władze austriackie przeniosty parafię do kościoła Najświętszej Marii Panny na Piasku, należacym do zakonu Ojców Karmelitów Trzewiczkowych. Kościół zostat zburzony na poczatku XIX wieku. Obecnie parafia pw. św. Szczepana i część wyposażenia z dawnego kościoła zostaty przeniesione do modernistycznego kościoła pod tym samym wezwaniem, mieszczacego się na ul. Sienkiewicza 19 w Krakowie (Rederowa, Studia, s. 107-108; Rożek, Nie istniejace kościoły, s. 102-105; W. Kęder, I. Kęder, Kościoły nieistniejące, w: Encyklopedia Krakowa, red. A.H. Stachowski, Warszawa-Kraków 2000, s. 451; Krasnowolski, Lokacje i rozwój, s. 370).

${ }^{65}$ Komendarz - wikary, będacy administratorem parafii. Zostaje wyznaczony przez biskupa i petni rozmaite obowiązki parafialne w zależności od zaistniatej sytuacji. W czasie wakatu urzędu proboszcza zastępuje go aż do czasu objęcia parafii przez nowego duszpasterza. W razie absencji proboszcza przez dluższy czas (związanej np. z petnieniem obowiąków poza parafia) również za zgoda biskupa kommendarz może zawiadywać parafia. Ponadto zostaje wysłany jako kapłan pomocniczy do proboszcza, który niedomaga fizycznie lub umysłowo. Komendarz ma więc te same obowiazki i prawa co proboszcz, nadane mu przez biskupa czasowo - komende, lecz władze zwierzchnie nie instaluja go kanonicznie (Z. Chodyński, Administrator parafii, w: Encyklopedja kościelna podtug teologicznej encyklopedji Wetzera $i$ Weltego, wyd. M. Nowodworski, t. 1, Warszawa 1873, s. 48; A.Kwieciński, Administrator parafii, w: Podręczna encyklopedya kościelna, t. 1-4, Warszawa 1904, s. 46).

${ }^{66}$ Józef Stefan Leon z Janowic Chwalibóg, herbu Strzemię - poseł województwa krakowskiego, wyższy województwa krakowskiego, sędzia sejmowy, prezes sądów ziemiańskich krakowskich, kawaler Orderu św. Stanisława. Pod koniec lat 80. XVIII wieku J. Chwalibóg zajmowat się porzadkowaniem swojego majątku. Po sprzedaniu ziem Zbigaty i Ilkowice (odziedziczone po ojcu Franciszku) oraz dokupieniu wsi Drożejowice nabyt grunty po kościele i parafii pw. św. Jakuba Starszego na Kazimierzu i tutaj też się osiedlit, aż do swojej śmierci w 1804 r. Pozostawit po sobie wdowę Pelagię Zborowska oraz pięcioro dzieci (Herbarz Polski, s. 127-128; A. Kamiński, Chwalibóg Józef Stefan Leon, w: PSB, t. 4, red. W. Konopczyński, Kraków 1937, s. 6-7; Urzędnicy województwa krakow- 
wiecznie trwać mająca transakcja, albo raczej sprzedażny niżej wyrażonych gruntów i placów kontrakt w następujący sposób. Pomieniony w[ielmo]żny imć ksiądz Rydulski, proboszcz ś. Szczepana i komendarz wzwyż rzeczonej niegdyś fary ś. Jakuba, stosując się do konsensu z władzy biskupiej krak[owskiej] pod dniem drugim miesiąca kwietnia roku teraźniejszego tysiąc sied[e]mset osiemdziesiąt siódmego z kancelarii biskupiej wypadłego ręką jw imć księdza Józefa Olechowskiego ${ }^{67}$, sufragana i archidiakona krako[wskiego], audytora ${ }^{68}$ i sędziego generalnego, orderu ś.go Stanisława kawaliera podpisanego, moc sprzedaży niżej wzmiankowanych placów i gruntów nadającego, takowe tedy place, ogrody, domy, tak proboszczo[w]ski jako też księży mansjonarzów, prebendarza, kapelana, do tegoż kościoła ś. Jakuba należące, tudzież i same mury kościoła i cmentarza ze wszystkiemi ich materiałami, niemniej ze wszystkiemi przyległościami i przynależytościami intra et extra moenia miasta Kazimierza zostającymi, a $\mathrm{z}$ dawien dawna do pomienionego kościoła ś. Jakuba należącymi, jako to folwarkiem na Podbrzeziu ${ }^{69}$ za murami miasta żydowskiego i wszystkimi gruntami do niego przynależącymi, gruntem nad Starą Wisłą ${ }^{70}$ przy Podbrzeziu leżącym, łąką z gruntem w kącie muru

skiego XVI-XVIII wieku. Spisy, t. 4: Małopolska, z. 2: Województwo krakowskie, oprac. S. Cynarski, A. Falniowska-Gradowska, red. A. Gąsiorowski, Kórnik 1990, s. 71, 97, 116, 216).

${ }^{67}$ Józef Olechowski, pierwotnie Oleszko, herbu Ratułd (1735-1806) - syn mieszczan Pawła Oleszki i Marianny z Kwiatkowskich, Iuris Utriusque Doctor (JUD), kawaler Orderu św. Stanisława. Od 1759 r. zmienił nazwisko na Olechowski. Biskup sufragan i archidiakon kapituly katedralnej na Wawelu od $1766 r$. Notariusz apostolski w krakowskiej Kurii z powołania biskupa Kajetana Sottyka (wówczas otrzymał prawo używania jako znaku notariuszowskiego herbu) i administrator diecezji w czasie niewoli biskupa Soltyka w Katudze. Kanonik kapituly kolegiaty sandomierskiej w latach 1767-1770 i kieleckiej do 1789 r. Brat udziat w reformach Kotłataja dotyczacych Wydziału Teologicznego Uniwersytetu Krakowskiego, a także po I Rozbiorze Polski byt jednym z negocjatorów z władzami austriackimi w rozmowach dotyczacych rozgraniczenia i zamiany dóbr kościelnych po rozbiorze (W.M. Bartel, Olechowski Józef, w: PSB, t. 23, red. E. Rostworowski, Wrocław-Warszawa-Kraków-Gdańsk 1978, s. 738-739; Szczepaniak, Spis prałatów, s. 13, 21, 36; tenże, Nekrologium, s. 135).

${ }^{68}$ Audytor - nazwa, będaca w użyciu kurii rzymskiej, na określenie urzędnika zajmującego posadę sędziego w kongregacjach lub radach, dawniej zwanych dykasteriami (Encyklopedia kościel$n a$, t. 1, s. 413-414).

${ }^{69}$ Podbrzezie, inaczej zwane Podbrzeże, Pobrzeze, Blechy - dawna osada rybacka na brzegu „Starej Wisty” (zob. przypis następny) na przedmieściach Kazimierza. Stanowiła pierwotnie wtasność miasta Kazimierza, a potem przeszła w posiadanie parafii pw. św. Jakuba Starszego na Kazimierzu $W$ dobie renesansu na tych terenach znajdowaty się posiadłości królowej Bony Sforzy, na które składały się liczne dwory i ogrody. Przedmieścia zniszczyli Szwedzi w czasie najazdu w połowie XVII wieku. Dziś po dawnej osadzie zachowała się jedynie nazwa jednej z ulic Starego Miasta, biegnacej wzdluż ul. Dietla (J. Bieniarzówna, J. M. Małecki, Dzieje Krakowa, t. 2: Kraków w wiekach XVI-XVIII, Kraków 1984, s. 185, 267; Encyklopedia Krakowa, s. 770).

${ }^{70}$ Stara Wista - pótnocne ramię Wisty, stanowiace główny nurt rzeki, rozdzielającej dzisiejsze dzielnice Stradom i Kazimierz. Za czasów Władysława Łokietka powstał na tej odnodze Wisty jedyny stały most zwany Królewskim, umożliwiający kupcom przeprawę na Kazimierz i dalej w stronę Wieliczki i Myślenic, skąd wiodła droga na Wegry i Ruś. Podczas powodzi w pierwszej połowie XIX wieku koryto Starej Wisty zostało zamulone i zamieniało się w bajoro, w którym zbierały się nieczystości i ścieki splywające ze Stradomia i Kazimierza. Zanieczyszczenia Starej Wisty i rozwijające się 
kazimierskiego za Bramą Bocheńską ${ }^{71}$ zwaną będącymi i z dawien dawna do tegoż probostwa ś. Jakuba należącymi, tudzież gruntem przez niegdy[ś] imć księdza Stanisława Gąsiorka ${ }^{72}$, proboszcza ś. Szczepana nabytym, nic tam dla kogożkolwiek nie zostawując, ani ekscypując ${ }^{73}$, ale tak, jak takowe place, grunta, ogrody wraz z wszystkimi pobudynkami na [s. 2] nich będącymi w swojej rozległości były i zostawały, są i dotąd zostają, i jak takowych ogrodów, placów i wszelkich pobudynków na nich zostających dawni proboszcze tegoż kościoła ś. Jakuba tudzież gruntu rzeczonego do probostwa ś. Szczepana nabytego dawni proboszcze tegoż ś. Szczepana i teraz będący trzymali i zażywali, trzymać i zażywać mieli pomienionemu jw imć panu Józefowi Chwalibogowi, sędziemu sejmowemu, wojskiemu wyższemu w[ojewó]dztwa krak[owskiego] i jego sukcesorom mocą, jako wyżej sobie daną, a to za sumę to jest za domy, place, ogrody, grunta, mury kościelne i cmentarza do tegoż probostwa ś. Jakuba należące sied[e]mnaście tysięcy zło[tych] pol[skich], za grunt zaś do probostwa ś. Szczepana przez rzeczonego niegdy[ś] imć księdza Gąsiorka nabyty tysiąc zło[tych] polskich sumę wraz złączoną os[ie]mnaście tysięcy zł[otych] polskich wynoszącą ${ }^{74}$ ustępuje, sprzedaje, daje i na wieczność rezygnuje, jako o tym donacja przed aktami autentycznymi urzędownie mająca być zeznana szerzej w sobie opiewać będzie, którą to sumę za grunta, domy i place jako wyżej teraz od[s]przedane od jw Chwaliboga należącą się takowym, tenże jw Chwalibóg wypłaca sposobem, to jest sied[e]mnaście tysięcy zło[tych] polskich za probostwo ś. Jakuba należące, a tysiąc zło[tych] polskich za grunt do probostwa ś. Szczepana przypadającą, tę jw Chwalibóg na do-

w nich bakterie doprowadzity w XIX wieku do kilku epidemii cholery, stąd też decyzja Rady Miasta zasypano dawne koryto. Obecnie na tych terenach mieszcza się Planty Dietlowskie, a inna pozostatościa tamtych czasów jest dawny most, który zachowat się jako wiadukt kolejowy nad ul. Grzegórzecka (K. Bąkowski, Dzieje Krakowa, Kraków 1911, s. 28-29; M. Borowiejska-Birkenmajerowa, Kształt średniowiecznego Krakowa, Kraków 1975, s. 172).

${ }^{71}$ Brama Bocheńska - jedna z głównych bram murów miejskich Kazimierza. Razem z Brama Wielicka znajdowała się w południowym odcinku murów. Wzniesiona między XIV a XV wiekiem. Zaopatrzona była $w$ most zwodzony. Zniszczona $w$ czasie najazdów szwedzkich została rozebrana w latach 50. XVII wieku (Konieczna, Studia nad przemieściami Krakowa, s. 33-34; J. Widawski, Miejskie mury obronne w państwie Polskim do poczatku XV wieku, Warszawa 1973, s. 178-179; Borowiejska-Birkenmajerowa, Ksztatt średniowiecznego Krakowa, s. 172).

72 Stanisław Gąsiorek, inaczej Stanisław z Bochni, S. Kleryka, S. Anserinus (ok. 1493-1562)syn Jakuba, poeta, kompozytor, duchowny. Kapelan kaplicy królewskiej w katedrze na Wawelu za czasów króla Zygmunta I Starego i dyrygent jego nadwornej kapeli - sam komponowat pieśni czy okolicznościowe utwory. Proboszcz w Wieliczce, kolegiacie wiślickiej, a także parafii pw. św. Szczepana w Krakowie (od 1546 r.), do której światyni, kosztem 70 złotych polskich ufundowat nowe organy (H. Barycz, Gąiorek (Anserinus) Stanisław, w: PSB, t. 7, red. W. Konopczyński, Kraków 1948-1958, s. 341-343; Bibliografia Literatury Polskiej - Nowy Korbut, t. 2: Piśmiennictwo Staropolskie, red. R. Pollak, Warszawa 1964, s. 319-320; Encyklopedia Krakowa, s. 236).

${ }^{73}$ Ekscypować - zwalniać od obowiazku, nie liczyć komuś, wyzwalać od czegoś (A. Karasiowa, Ekscypować, w: Stownik polszczyzny XVI wieku, red. M.R. Mayenowa, t. 6, Wrocław-Warszawa -Kraków-Gdańsk 1972, s. 536).

${ }^{74}$ W oryginale obok stowa wynoszącą na marginesie zapisano czerwona kreda liczbę 18 i podkreślono ją. 
brach swoich dziedzicznych wsi Zbikałach ${ }^{75} \mathrm{w}$ w[ojewó]dztwie krak[owskim], powiecie Księskim leżących na procent po zł[otych] polskich trzy ${ }^{76}$ i pół od każdego sta mający być rachowany corocznie dwiema ratami decursive to jest od sumy sied[e]mnastu tysięcy zło[tych] polskich do rąk imć księdza administratora tych prowentów teraz i na potem będącego lub tego komu by ta suma kapitalna dysponowana była wypłacać mianej, a od tysiąca zł[otych] polskich podobnież do rąk imć księdza proboszcza ś.go Szczepana teraz i na potem będącego podobnież wypłacać powinnej ${ }^{77}$ lokuje i zabezpiecza tudzież zapis urzędowny na sumę wzwyż wzmiankowaną wraz złączoną os[ie]mnaście tysięcy zło[tych] polskich zeznać obliguje się. A lubo teraz jw Chwalibóg sumę pomienioną na procent na dobrach swoich zapisuje, prowizja jednak od takowej teraz zapisanej, dopiero od dnia i święta śś. ${ }^{78}$ Trzech Króli Rzymskich w roku da Bóg przyszłym ${ }^{79}$ [s. 3] przyszłym tysiąc sied[e]mset os[ie]mdziesiątym ósmym, do wypłacania ratami dwiema, to jest pierwszą na dzień i święto ś. Jana Chrzciciela, drugą na dzień i święto śs. Trzech Króli zaczynać się będzie powinna i tak następnie w insze lata takowa prowizja ratami wzmiankowanymi na ś. Jana i na Trzy Króle do rąk jako wyżej za kwitami ręcznymi opłacana być będzie powinna. Ostrzega to w[ielmożny] imć ksiądz Rydulski, ażeby miejsce cmentarza i samego kościoła, (który do rozebrania jako materiał z niego zakupiony pozwala się $)^{80}$ na podłe używanie obrócone niebyły, ile że miejsca też od szacunku wyłączone zostały, ale na tych figura lub kapliczka d[1]a wiecznej pamiątki zostawała. A że niektórzy poseserowie na gruntach teraz odsprzedanych znajdują się, a szczególniej dane prawo emphiteutyczne ${ }^{81}$ na grunt ś. Szczepana i lubo kondycji w tym prawie opisanej tenże posesor nie dopełnił, przez co od prawa swego odpada i odpaś powinien, gdyby jednak z jakowego przypadku stamtąd ruszony być nie mógł, tedy w[ielmo]żny imć ksiądz Rydulski sumę tysiąc zło[tych] polskich za grunt ten teraz zapisaną powrócić lub z zapisanej zalikwidować obligowanym będzie, inne zaś pretensje innych posesorów, gdyby jakowe pokazały się, te w[ielmo]żny imć ksiądz Rydulski do zaspoko-

${ }^{75}$ Zbikaty, inaczej zwane Dzwikaty albo Dzbical - dziś Zbigaty-Ilkowice, wieś oddalona ok. $2 \mathrm{~km}$ od Janowic, ok. $10 \mathrm{~km}$ od Książa Wielkiego i ok. $16 \mathrm{~km}$ od Miechowa. W XVIII wieku należała do powiatu ksiaskiego, obecnie znajduje się w powiecie miechowskim (Zbigaty, w: SGKP, red. B. Chlebowski, J. Krzywicki, F. Sulimierski, W. Walewski, t. 14, Warszawa 1895, s. 517; Z. Leszczyńska-Skrętowa, Dąbie, w: Słownik historyczno-geograficzny województwa krakowskiego w średniowieczu, cz. 1, oprac. J. Laberschek, Z. Leszczyńska-Skrętowa, F. Sikora, Wrocław 1985, s. 506).

${ }^{76}$ Na marginesie przed stowem ,, trzy” zapisano liczbe 31/2, a pod spodem 16.

${ }^{77}$ W oryginale za druga litera , , $n$ " maty kleks.

${ }^{78}$ W oryginale litery , ss” nadpisane na tekście później. Skryba nadpisat te litery także przy kolejnych wzmiankach o Trzech Królach.

${ }^{79}$ W oryginale stowo zapisane poniżej tekstu głównego.

${ }^{80}$ W oryginale fraza zapisana $w$ nawiasie zaznaczonym dwukropkiem i pojedyncza kreska pionowa.

${ }^{81}$ Prawo emfiteutyczne - prawo wieczystej dzierżawy, danej na kolejne lata, pokolenia lub spadkobierców o niskim czynszu. Nie można było jej dzielić, lecz przechodziła ona na kolejne pokolenia lub spadkobierców. Można byto także przelać ja na inna osobę (A. Brückner, Encyklopedia staropolska (dalej: ES), t. 1, Warszawa 1939, s. 319-320). 
jenia na siebie bierze, tudzież podymne ${ }^{82}$ teraźniejsze marcowe do zapłacenia na siebie przejmuje, tak ażeby w tych okolicznościach jw Chwalibóg żadnej od nikogo nie miał impetycji ${ }^{83}$. Ponieważ zaś miasto Kazimierz zapozwało na komisję porządkową kazimierską posesorów gruntów teraz odsprzedanych, więc gdyby co $\mathrm{od}^{84}$ takowych gruntów i pobudynków odpaść miało, tedy w[ielmo]żny imć ksiądz Rydulski według wymiaru i taksy jw Chwalibogowi bonifikować ${ }^{85}$ obliguje się. Nawzajem gdyby co gruntu więcej nad od[s]przedane teraz przypaść miało, więc potrąciwszy ekspens na windykowanie tego łożoną, resztę także według wymiaru i taksy jw Chwalibóg zapłacić przyrzeka. A gdy przy spisaniu niniejszej transakcji w[ielmo]żny imć ksiądz Rydulski, teraz odsprzedane grunta, place, domy, kościół, pobudynki w aktualną jw Chwalibogowi oddaje posesję, przeto gdyby jakowy prowent przez w[ielmożnego] imć księdza Rydulskiego stamtąd wzięty być [s. 4] okazał się, takowy jw Chwalibogowi bonifikowany być powinien. Intromisji $^{86}$ do tychże placów, gruntów, ogrodów, domów i pobudynków jako exnunc w[ielmo]żny imć ksiądz Rydulski władzą jako wyżej sobie daną jw Chwalibogowi niniejszym dopuszcza kontraktem. Tak ta, gdy na gruncie brana będzie ani przez siebie, ani przez kogo innego broniona nie będzie i owszem ewikcją ${ }^{87}$ od wszelkich impetycji względem od[s]przedanych tychże gruntów i pobudynków generalną, a osobliwie na sumie wzwyż rzeczonej os[ie]mnastu tysięcy zło[tych] polskich za tąż sprzedaż na dobrach jako wyżej zapisanej zapisuje. Dokumenta jakowe tylko do od[s]przedanych teraz gruntów w[ielmo]żny imć ksiądz Rydulski mieć może, takowe jw Chwalibogowi oddać przyrzeka. Co wszystko i każdą rzecz z osobna strony obydwie, to jest w[ielmo]żny imć ksiądz Rydulski z[e] swymi następcami, a jw Chwalibóg z[e] swymi sukcesorami strzymać i ziścić sobie przyrzekają, a to pod szkodami ziemskimi na proste słowo mającymi być otaksowanymi, a wniedosyć uczynieniu forum ziem[iań]stwa lub grodu w[ojewó]dztwa krak[owskiego] do odpowiadania sobie, następcom i względnie sukcesorom swoim naznaczają i ten kontrakt rękami własnymi podpisawszy aktami ziemskimi krakowskimi roborują ${ }^{88}$. Działo się w Krakowie, dnia szóstego miesiąca kwietnia roku pańskiego 1787.

${ }^{82}$ Podymne, inaczej zwane podymowe, podworowe - opłata poczatkowo placona od gruntu, na którym znajdowat się dom, potem czynsz wprowadzony od 1629 r. uchwała sejmowa, płacony w miastach od domu, czyli dymu wedle jego wielkości. (ES, t. 2, s. 173-174).

${ }^{83}$ Impetycja - rozszerzenie praw lub dochodzenie swoich pretensji do poszczególnych dóbr (M. Arct, M. Arcta stownik ilustrowany języka polskiego (dalej: Arct), t. 1, Warszawa 1916, s. 442).

${ }^{84}$ W oryginale słowo nadpisane na tekście później.

${ }^{85}$ Bonifikować - wynagrodzić stratę lub niedobór (Arct, t. 1, s. 68).

${ }^{86}$ Intromisja - wwiazanie. Akt prawny, zawarty w obecności woźnego i dwóch świadków ze szlachty, wprowadzający nowego dziedzica w posiadanie dóbr i przenoszacy na niego własność. Intromisja dodatkowo była aktem potwierdzajacym inskrypcje, czyli wpisanie transakcji do ksiag wieczystych ziemskich (ES, t. 1, s. 463).

${ }^{87}$ Ewikcja-ubezpieczenie. Rodzaj warunku podczas sprzedaży, polegajacy na tym, że sprzedajacy zobowiązany jest zabezpieczyć nabywajacego od przyszlych roszczeń w odniesieniu do danych dóbr, czy procesów, na których to sprzedawca reprezentuje nabywcę, a w razie niepomyślnych rozstrzygnięć zwraca mu wszelka szkodę (ES, t. 1, s. 320).

${ }^{88}$ Roborować - przyznać urzędownie i zatwierdzić (Arct, t. 2, s. 516). 
Ks[iądz] Piotr Rydulski, kościołów kolegiaty ś. Anny kanclerz, św[iętego] Szczepana proboszcz, ś. Jakuba komendarz, Seminarium Akademickiego prefekt $\mathrm{m}[\mathrm{anu}] \mathrm{p}$ [ropria].

Józef z Janowic Chwalibóg S[ędzia] S[ejmowy], W[ojski] W[yższy] W[ojewództwa] K[rakowskiego] m[anu] p[ropria].

In actis terrestribus Cracoviensibus feria sexta magna post dominicam Ramis Palma[rum], proxima die scilicet sexta mensis aprilis anno domini 1787. Contractus $\mathrm{p}[\mathrm{rae}]$ sentis resignatorii, circa mutua[m] illius sub actu supra[s]cripto in actis $\mathrm{t}[\mathrm{e}] \mathrm{rr}[\mathrm{estr}]$ ibus Cracovien[sibus] $\mathrm{p}$ [er] partes ${ }^{89}$ subsecutam roborationem, intercessit Ingrossatio. Quod attestor Rudowski. V[ice] N[otarius] C[racoviensis] $\operatorname{Pr}[\text { aefec]tus. [podpis }]^{90}$

\section{REFERENCES / BIBLIOGRAFIA}

\section{Źródla}

Archiwum Klasztoru Kanoników Regularnych Laterańskich w Krakowie (AKKRL)

b. sygn., Historya ks. ks. Kanoników Regularnych Lateraneńskich w Polsce od roku 1750 do r. 1857 wyjęta z pamiętników ks. Piotra Studentowicza, członka Zgromadzenia krakowskiego.

sygn. I-A-1, Liber mortuorum in parochia S[ancti]s[imi] Corporis Christi Casimiriae ad Cracoviam ab anno $1797 \mathrm{ad}$ annum 1812. Tomus I.

Archiwum Kurii Metropolitarnej w Krakowie (AKMKr)

sygn. Acta Episcopalia (AEp) 113.

sygn. Acta Episcopalia (AEp) 118.

sygn. Acta Officialia (AOff) 188.

Archiwum Narodowe w Krakowie (ANK)

sygn. K-887, Akta miasta Kazimierza pod Krakowem, Visitatio ecclesiae parochialis sanc-

ti Jacobi Apostoli Casimiriae ad Cracoviam, die 13 mensis Martii, anni d[omi]ni 1748.

Archiwum Uniwersytetu Jagiellońskiego (AUJ)

sygn. 5164-5166, Akta papierowe 41/1.

Biblioteka Jagiellońska (BJ)

sygn. rkp 1061, Summaryusz praw y dokumentow koscioła farnego swiętego Jakoba Aposoła na Kazimierzu przy Krakowie.

sygn. rkp 2580, Wykaz domów miasta Krakowa wraz z zmianą ich właścicieli od r. 1790 do r. 1846 przez Konstantego Fijałkowskiego, urzędnika W[olnego] M[iasta] Kr[akowa] sporządzony.

\footnotetext{
${ }^{89}$ W oryginale stowa per partes nadpisane na tekście później.

${ }^{90}$ W oryginale poniżej w prawym dolnym narożu zapisano czerwona kreda: $2390 . \mathrm{m}$.
} 
sygn. rkp 5357, Teki Żegoty Paulego, Notaty luźne do historii m. Krakowa i okolicy: wypisane $\mathrm{z}$ akt grodzkich, miejskich i kapitulnych krakowskich. T. 7, Acta consularia i acta scabinalia Casimiriensia.

sygn. rkp 5357, Teki Żegoty Paulego, Notaty luźne do historii m. Krakowa i okolicy: wypisane z akt grodzkich, miejskich i kapitulnych krakowskich. T. 10, Katedra, kościoły, klasztory w Krakowie i na Kazimierzu.

Franciszek Cezary, Przewodnik abo kościołów krakowskich krótkie opisanie wydany w 1603 z widokami Krakowa, którego już nie ma, oprac. J. Kiliańczyk-Zięba, Kraków 2002.

„Gazeta Krakowska”, niedziela 30 września 1804 r., dodatek do nr 79.

Kodeks Dyplomatyczny miasta Krakowa 1257-1506, cz. 2-4, wyd. F.K. Piekosiński, Kraków 1882.

Pruszcz Piotr Hiacynt, Kleynoty stołecznego miástá Krakowa, albo koscioły, y co w nich iest widzenia godnego y znácznego, przez Piotra Hiacyntha Prvszcza, krotko opisane, Powtornie záś z pilnośćia przeyźrzáne, y do druku z additámentem nowych Kośćiołow y Relikwii S. podane, z pozwoleniem Zwierzchnośći Duchowney roku pańskiego 1745 , Kraków 1861.

\section{Opracowania}

Arct Michał, M. Arcta stownik ilustrowany języka polskiego, t. 1-3, Warszawa 1916.

Baczkowska Wanda, Rydulski Piotr Józef Jan Kanty, w: Polski Słownik Biograficzny, t. 33, red. H. Markiewicz, Wrocław-Warszawa-Kraków 1991-1992, s. 428-429.

Baczkowska Wanda, Stęplowski (Stemplowski) Kazimierz Franciszek, w: Polski Słownik Biograficzny, t. 43, red. E. Rostworowski, Warszawa-Kraków 2004, s. 537-540.

Bartel Wojciech Maria, Olechowski Józef, w: Polski Słownik Biograficzny, t. 23, red. E. Rostworowski, Wrocław-Warszawa-Kraków-Gdańsk 1978, s. 738-739.

Barycz Henryk, Gasiorek Stanisław, w: Polski Stownik Biograficzny, t. 7, red. W. Konopczyński, Kraków 1948-1958, s. 341-343.

Bąkowski Klemens, Dzieje Krakowa, Kraków 1911.

Bieniarzówna Janina, Małecki Jan Marian, Dzieje Krakowa, t. 2: Kraków w wiekach XVI-XVIII, Kraków 1984.

Bibliografia Literatury Polskiej - Nowy Korbut, t. 2: Piśmiennictwo Staropolskie, red. R. Pollak, Warszawa 1964.

Borowiejska-Birkenmajerowa Maria, Kształt średniowiecznego Krakowa, Kraków 1975. Brückner Aleksander, Encyklopedia staropolska, t. 1-2, Warszawa 1939.

Chodyński Zenon, Administrator parafii, w: Encyklopedja kościelna podtug teologicznej encyklopedji Wetzera i Weltego, wyd. M. Nowodworski, t. 1, Warszawa 1873, s. 48.

Chotkowski Władysław, Księdza Prymasa Poniatowskiego spustoszenie kościelne w Krakowie: przyczynek do dziejów Uniwersytetu, Warszawa-Kraków 1918.

Ekielski Eustachy, Miasto Kazimierz i budowle akademickie w tem mieście, Kraków 1869.

Encyklopedja kościelna podtug teologicznej encyklopedji Wetzera i Weltego, wyd. M. Nowodworski, t. 1-33; S. Biskupski, t. 33, Warszawa-Płock 1873-1933.

Encyklopedia Krakowa, red. A.H. Stachowski, Warszawa-Kraków 2000.

Estreicherówna Maria, Wykaz zniesionych kościołów, kaplic i klasztorów w Krakowie, „Kalendarz Katolicki Krakowski”, 9 (1889) s. 105-119.

Follprecht Kamila, Zmiany własności nieruchomości w Krakowie zwiąane z kasatami klasztorów przełomu XVIII i XIX w., „Hereditas Monasteriorum”, 5 (2014) s. 27-41. 
Gach Piotr Paweł, Kasaty zakonów na ziemiach dawnej Rzeczypospolitej i Ślaska 17731914, Lublin 1984.

Herbarz Polski, cz. 1: Wiadomości historyczno-genealogiczne o rodach szlacheckich, t. 3, wyd. Adam Boniecki, Warszawa 1900.

Goras Magdalena, Zaginione gotyckie kościoły Krakowa, Kraków 2003.

Instrukcja wydawnicza dla źródet historycznych od XVI do połowy XIX wieku, red. K. Lepszy, Warszawa 1953.

Kamiński Adam, Chwalibóg Józef Stefan Leon, w: Polski Stownik Biograficzny, t. 4, red. W. Konopczyński, Kraków 1937, s. 6-7.

Karasiowa Anna, Ekscypować, w: Słownik polszczyzny XVI wieku, red. M.R. Mayenowa, t. 6, Wrocław-Warszawa-Kraków-Gdańsk 1972, s. 536.

Karaskiewicz Katarzyna, Prymasa Poniatowskiego potyczki w Akademii Krakowskiej, „Przegląd Historyczny”, 88 (1997) nr 1, s. 53-71.

Katalog zabytków sztuki w Polsce, t. 4: miasto Kraków, cz. 4: Kazimierz, Stradom, Kościoty i klasztory 1, red. I. Rejduch-Samkowa, J. Samek, Warszawa 1994.

Kęder Wojciech, Kęder Iwona, Kościoły nieistniejace, w: Encyklopedia Krakowa, red. A.H. Stachowski, Warszawa-Kraków 2000, s. 450-451.

Konieczna Wanda, Poczatki Kazimierza (do r. 1419), w: Studia nad przedmieściami Krakowa, Kraków 1938, s. 7-90.

Krasnowolski Bogusław, Ulice i place krakowskiego Kazimierza: z dziejów Chrześcijan i Żydów w Polsce, Kraków 1992.

Krasnowolski Bogusław, Lokacje i rozwój Krakowa, Kazimierza i Okołu. Problematyka rozwiązań urbanistycznych, w: Kraków. Nowe studia nad rozwojem miasta, red. J. Wyrozumski, Kraków 2007, s. 355-426.

Krasnowolski Bogusław, Krakowski Kazimierz w dobie upadku: od najazdu szwedzkiego (1655-1657) do dzieła Komisji Dobrego Porzadku (1786-1791) i trzeciego rozbioru Polski (1795), „Krzysztofory”, (2009) nr 27, s. 139-158.

Krzyżanowski Stanisław, Wstęp historyczny, „Rocznik Krakowski”, 6 (1904) s. 1-14.

Kumor Bolesław Stanisław, Granice (archi)diecezji krakowskiej (1000-1939), „Prawo Kanoniczne: kwartalnik prawno-historyczny”, 6 (1963) z. 1-4, s. 545.

Kumor Bolesław Stanisław, Dzieje diecezji krakowskiej do roku 1795, red. Z. Chełmicki, t. 1-4, Kraków 1998-2002.

Kwieciński Apolinary, Administrator parafii, w: Podręczna encyklopedya kościelna, red. Z. Chełmicki, t. 1-4, Warszawa 1904, s. 46.

Lalik Tadeusz, Zagadnienie ,vita communis” kapitut polskich XII wieku, w: Wieki średnie. Medium aevum, red. A. Gieysztor, M. Serajski, S. Trawkowski, Warszawa 1962, s. 99-110.

Leszczyńska-Skrętowa Zofia, Dąbie, w: Słownik historyczno-geograficzny województwa krakowskiego w średniowieczu, cz. 1, oprac. J. Laberschek, Z. Leszczyńska-Skrętowa, F. Sikora, Wrocław 1985, s. 506.

Łatak Kazimierz, Kongregacja krakowska kanoników regularnych laterańskich na przestrzeni dziejów, Kraków 2002.

Maciejowski Wacław Andrzej, Polska aż do pierwszej połowy XVII wieku pod względem obyczajów i zwyczajów w czterech częściach opisana, t. 1, Petersburg-Warszawa 1842.

Myszka Marian, Dawne cmentarze Krakowa w świetle badań archeologicznych, w: Cmentarz Rakowicki w Krakowie, Kraków 2003, s. 121-144.

Podręczna encyklopedya kościelna, oprac. S. Gall, J. i R. Archutowscy, t. 1-49, Warszawa-Lublin-Łódź-Poznań 1904-1914. 
Polski Słownik Biograficzny, t. 1-52, red. E. Rostworowski i in., Wrocław-Warszawa-Kraków-Gdańsk-Łódź 1935-2019.

Radwański Kazimierz, Kraków przedlokacyjny: rozwój przestrzenny, Kraków 1975.

Radwański Kazimierz, Problemy badawcze wczesnośredniowiecznego Krakowa, w: Kraków przedlokacyjny. Materiaty sesji naukowej z okazji Dni Krakowa w 1984 roku, Kraków 1987, s. 9-27.

Radzikowski Walery Eljasz, Kraków dawny i dzisiejszy, Kraków 1902.

Rajman Jerzy, Średniowieczne patrocinia krakowskie, Kraków 2002.

Rożek Michał, Nie istniejące kościoty Krakowa, „Biuletyn Biblioteki Jagiellońskiej”, 33 (1983), s. 95-120.

Rożek Michał, Przewodnik po zabytkach i kulturze Krakowa, Kraków 1997.

Rederowa Danuta, Studia nad wewnętrznymi dziejami Krakowa porozbiorowego (1796-1809), część I: Zagadnienia urbanistyczne, „Rocznik Krakowski”, 34 (1957) s. $62-177$.

Słownik geograficzny Królestwa Polskiego i innych krajów słowiańskich, red. F. Sulimierski, B. Chlebowski, W. Walewski, J. Krzywicki, t. 1-15, Warszawa 1880-1902.

Słownik historyczno-geograficzny województwa krakowskiego w średniowieczu, cz. 1-5, Kraków 1980-2019.

Słownik polskich teologów katolickich, red. H.E. Wyczawski, t. 1-4, Warszawa 1981-1983.

Słownik polszczyzny XVI wieku, red. M.R. Mayenowa, S. Bąk, K. Mrocewicz, t. 1-37, Wrocław-Warszawa-Kraków-Gdańsk-Łódź 1966-2016.

Szczepaniak Jan, Spis prałatów i kanoników kapituły katedralnej oraz kapituł kolegiackich diecezji krakowskiej XVIII w., Kraków 2008.

Szczepaniak Jan, Nekrologium. Księża diecezji krakowskiej zmarli w latach 1749-1810, Kraków 2010.

Szymański Józef, Poczatki prepozytur $w$ diecezji krakowskiej, „Roczniki Teologiczno-Kanoniczne", 9 (1962) z. 1, s. 65-76.

Szymański Józef, Wokót genezy organizacji parafialnej w Polsce, „Przegląd Historyczny", 55 (1964) nr 3, s. 501-508.

Szymański Józef, Kanonikat świecki w Małopolsce od końca XI do połowy XIII wieku, Lublin 1995.

Ściężor Tomasz, Historyczny Prokocim: Monografia wsi podkrakowskiej XIV-XX w., Kraków 2008.

Świszczowski Stefan, Miasto Kazimierz pod Krakowem, Kraków 1981.

Tazbirowa Julia, W sprawie badań nad geneza organizacji parafialnej $w$ Polsce, „Przegląd Historyczny", 54 (1963) nr 1, s. 85-92.

Tomkowicz Stanisław, Ulice i place Krakowa w ciagu dziejów. Ich nazwy i zmiany postaci, Kraków 1926.

Urzędnicy województwa krakowskiego XVI-XVIII wieku. Spisy, t. 4: Małopolska, z. 2: Województwo krakowskie, oprac. S. Cynarski, A. Falniowska-Gradowska, red. A. Gąsiorowski, Kórnik 1990.

Walczak Katarzyna, Klejnot miasta zaginiony. Zarys dziejów krakowskiego kościoła Wszystkich Świętych do końca XVI wieku, „Folia Historica Cracoviensia”, 19 (2013) s. 133-158.

Widawski Jarosław, Miejskie mury obronne w państwie Polskim do początku XV wieku, Warszawa 1973.

Wiśniowski Eugeniusz, Kościół parafialny i jego funkcje społeczne w średniowiecznej Polsce, „Studia Theologica Varsaviensia”, 7 (1969) nr 2, s. 187-237. 
Wolski Marian, Nie istniejący kościót pod wezwaniem św. Jakuba Starszego na Kazimie$r z u$, „Rocznik Krakowski”, 61 (1995) s. 11-26.

Wolski Marian, Trzeciescy herbu Strzemię. Małopolska rodzina szlachecka XIV-XVI wieku, Kraków 2005.

Wysocki Jan, Żołędzikowski Antoni Józef, w: Słownik polskich teologów katolickich, red. H.E.Wyczawski, t. 4, Warszawa 1983, s. 554-555.

Zielińska Zofia, Poniatowski Michał Jerzy, w: Polski Słownik Biograficzny, t. 27, red. E. Rostworowski, Wrocław-Warszawa-Kraków-Gdańsk-Łódź 1983, s. 455-471.

Żaki Andrzej, Badania archeologiczne na terenie Krakowa w roku 1956 (seria IV), „Sprawozdania Archeologiczne", 5 (1959), s. 229-236.

Żaki Andrzej, Sprawozdanie z badań nad przedlokacyjnym Krakowem w 1957 roku (seria V), „Sprawozdania Archeologiczne”, 15 (1963), s. 329-336.

Żaki Andrzej, Badania nad przedlokacyjnym Krakowem w latach 1958-1961 (serie VI-IX), ,Sprawozdania Archeologiczne”, 15 (1963), s. 336-351.

Żaki Andrzej, Archeologia Małopolski wczesnośredniowiecznej, Kraków 1974. 


\title{
THE LAST YEARS OF THE FUNCTIONING \\ OF ST. JAMES THE GREATER CHURCH \\ AND PARISH IN CRACOVIAN KAZIMIERZ (1758-1787)
}

\begin{abstract}
The article presents the last years of the existence of St. James the Greater church and parish in Cracovian Kazimierz (a district of the city of Kraków). The currently non-existent St. James church was one of the three oldest churches in Kazimierz, next to the churches of St. Michael the Archangel on Skałka and St. Laurence in the village of Bawół. It was located in the centre of a settlement belonging to the forbear of the Strzemien family, whose name is presently unknown. The first mention of the parish of St. James comes from 1313. Right from the outset of its existence, it was served by two parish priests. In 1462 , a document was issued reorganizing the structure of the clergy performing ministry in the temple of St. James in Kazimierz, abolishing the second parsonage, and establishing a college of missionaries in its place. The remaining parson position, in line with the common practice observed in the 15th century, was elevated to the dignity of a provostry. The time frame for the article is delineated by two 18 th century dates. In 1758, representatives of the Strzemien family relinquished the right of patronage over the parish of St. James in favour of the bishops of Kraków. In the same year, the Bishop of Kraków, Andrzej Stanisław Kostka Załuski, incorporated the parish into the prefecture of the Kraków Academic Seminary. In 1783, as part of the so-called ecclesiastical „clearing”, carried out on the orders of Primate Michał Jerzy Poniatowski, the parish of St. James the Apostle in Kazimierz was finally dissolved. The post-church grounds: the walls of the temple, the garden, the houses of the parson, vicars, prebendary and chaplain as well as the parish cemetery with all the materials were sold in 1787 by Rev. Piotr Józef Rydulski to Józef Chwalibóg of Janowice, who demolished the temple the same year. The text of the sales contract between Rev. P.J. Rydulski and J. Chwalibóg has been included as an appendix to the article.
\end{abstract}

Keywords: Józef Chwalibóg of Janowice; Kazimierz near Kraków; church of St. James the Greater; Michał Jerzy Poniatowski; Piotr Józef Rydulski; Strzemień family 